\title{
POSTGLACIAL DEFORMATION HISTORY OF SACKUNGEN ON THE NORTHERN SLOPE OF PIC D'ENCAMPADANA, ANDORRA (manuscript v.4; 08-JAN-2019)
}

\author{
J.P. McCalpin, J. Corominas
}

\begin{abstract}
The northern slope of Pic d'Encampadana descends steeply $800 \mathrm{~m}$ down into the glaciated Valira d'Orient Valley of Andorra, in the eastern Pyrenees. This high, steep slope is underlain by foliated metamorphic rocks (slates, phyllites) and has long been known for its numerous antislope scarps (sackungen), indicative of deep-seated gravitational slope deformation (DSGSD). We excavated trenches across antislope scarps and their adjacent troughs at three locations, to expose the trough stratigraphy, to map and date the deformation structures, and to infer slope kinematics at each location. Sackung troughs formed at Encampadana have acted as sediment traps since formation, and are underlain by distinctive post-faulting strata that permit reconstructing the evolution of the scarp/trough pair. The oldest strata exposed in our 2$2.5 \mathrm{~m}$-deep trenches are coarse, angular talus deposited as slope-mantling sediments predating the modern narrow sackung scarps and troughs. These deposits have been disrupted by normal and reverse faulting, with the largest fault zone underlying the antislope scarp and dipping into the slope at $40^{\circ}-80^{\circ}$. Each trench contains subsidiary north-dipping normal faults beneath the southern edge of the trough, giving the appearance of a graben. In two of three trenches postfaulting deposits have subsequently been tilted or folded down toward the main fault, as if sagging into a void space created by horizontal extension and/or outward toppling of the footwall. The trough fill is generally dominated by poorly-sorted sandy slopewash, but does contain two other important facies: (1) thin clay and silt deposits deposited in standing water, found beneath the center of the trough, and (2) gravelly scarp-derived colluvial wedges, found beneath the edges of the trough. Paleosols have formed on the top of fining-upward sequences of strata, permitting interpretation of several cycles of: (1) episodic downdropping along graben faults and deepening of the topographic trough, (2) filling the trough with marginal colluvial and axial sag-pond sediments, followed by (3) a hiatus of soil profile development. Despite their shallow depths, each trench preserves evidence of multiple unconformities and 3 to 5 deformation events, recognized by: (1) upward termination of faults at various stratigraphic levels; (2) angular unconformities between trough infill units or fining-upward packages; and (3) by coarse, angular colluvial deposits that thin away from the footwall (scarp-derived colluvial wedges). The average time between deformation events in any one trench in the past 12-15 ka is about 3-3.5 ka. Deformation seems to have begun first in the lower part of the northern slope (Trench 2, $1935 \mathrm{~m}$ elevation) about $15.3 \mathrm{ka}$, and had spread to the upper parts of the slope (Trench 3, $2320 \mathrm{~m}$ ) by $11.6 \mathrm{ka}$. Deformation in the lower slope ceased after $5.5 \mathrm{ka}$, but still continued higher on the slope into the mid-late Holocene. The youngest deformation dated (1.4$1.6 \mathrm{ka})$ occurred in the highest trench on the slope. This pattern of younger deformation with increasing elevation has been documented at several other sites (e.g., Panek and Klimes, 2016) and has been ascribed to an upslope-migrating extensional stress field which originated at the base of the slope from glacial oversteepening and end-glacial debuttressing.
\end{abstract}




\section{Introduction}

The formerly glaciated valleys of Andorra, like valleys elsewhere in the Pyrenees, display abundant landforms attesting to post-glacial rock slope failure (Jarman et al., 2014). In the Valira d'Orient (Fig. 1) a large trunk glacier has eroded a U-shaped valley in multiple Pleistocene glaciations to a depth of $600 \mathrm{~m}$ below the global Late Glacial Maximum (LGM) trimline. The valley walls in central Andorra are composed of relatively weak, foliated Paleozoic slates and phyllites, similar to those studied by Zischinsky (1966) in his classic early paper about sackungen.

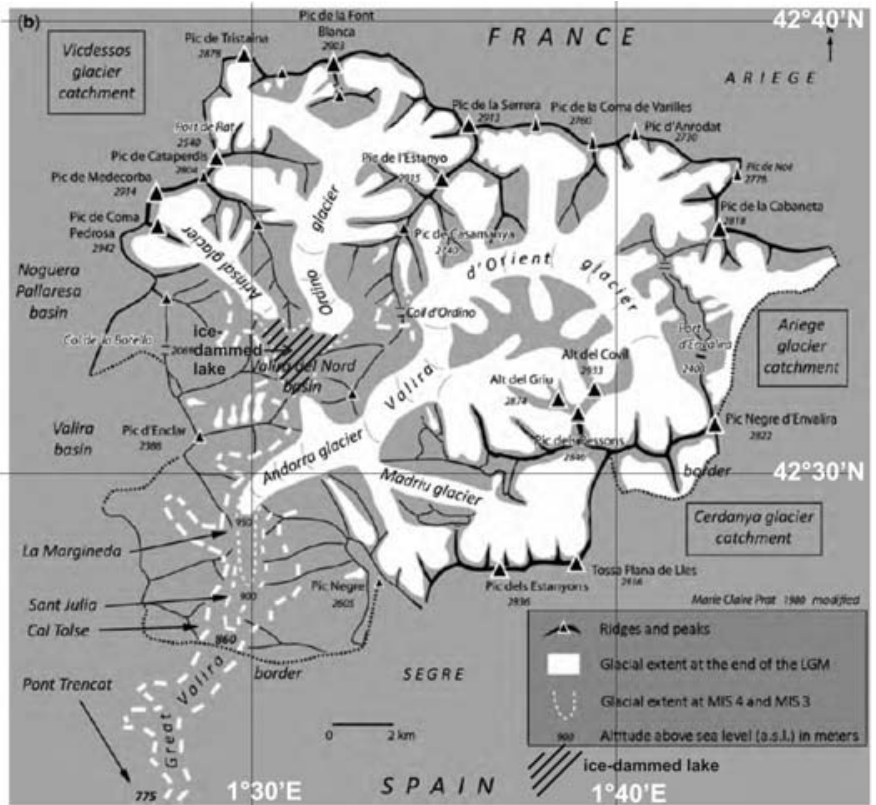

Fig. 1. Late Pleistocene ice extent at the end of the global Late Glacial Maximum (LGM) in Andorra, in relation to the Encampadana study area (box at center; also the area of Figs. 4 and 6). Canillo village is located at the NW corner of the box. Adapted from Turu et al, 2016.

This combination of deep valleys, steep valley sidewalls, weak foliated rocks, and moderate precipitation (1100 mm/yrin Canillo village)has spawned a wide spectrum of postglacial slope failures, including (in order of increasing size) slumps, earthflows, rockslides, and deep-seated gravitational slope deformation (DSGSD). This study focuses on the well-known DSGSD landforms on the northern slope of Pic d'Encampadana, which lies directly west of the GrandValira - Soldeu ski resort (Fig. 2). 


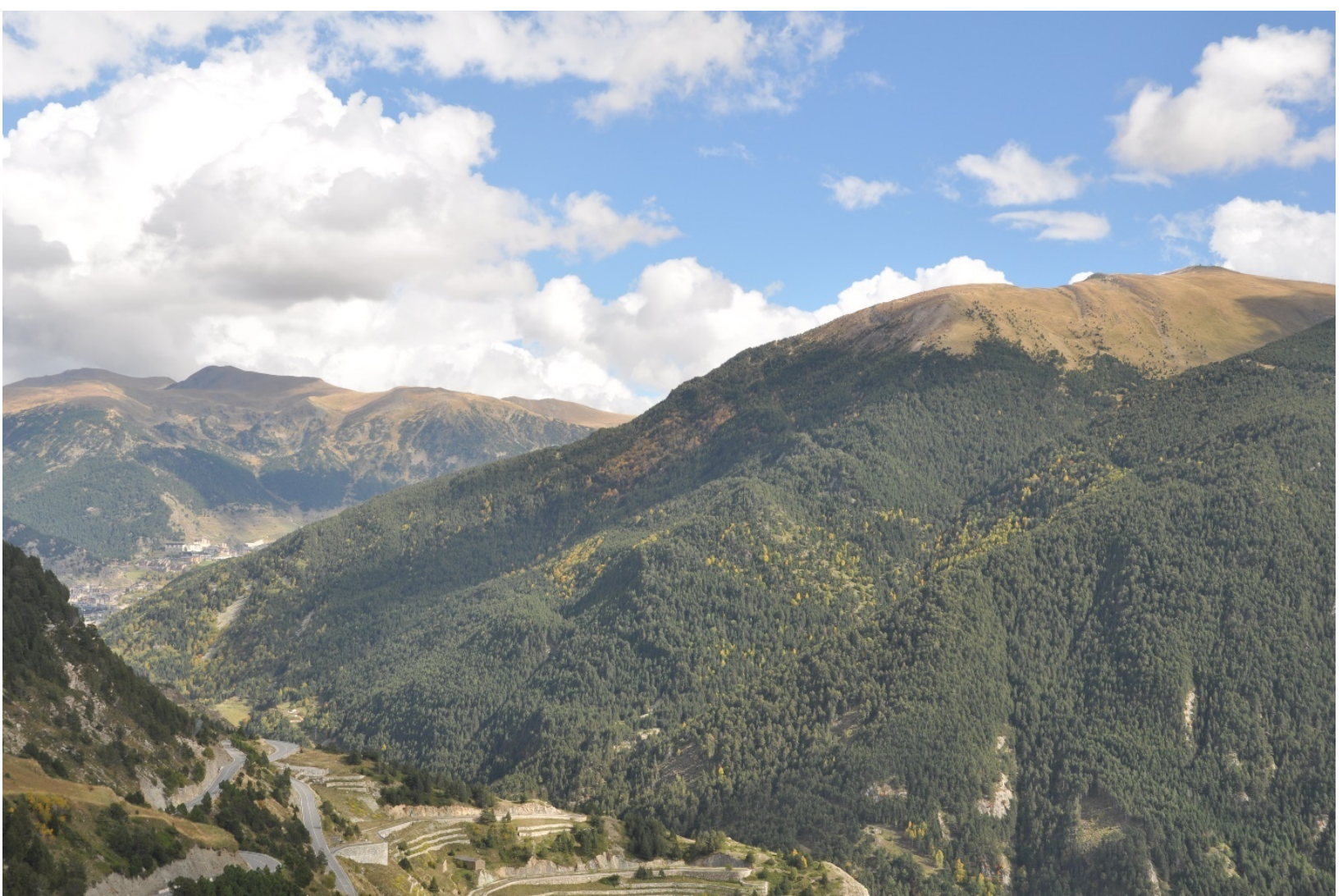

Figure 2. Overall view of the northern slope of the Encampadana massif (center) looking East, with Pic d'Encampadana $(2472 \mathrm{~m}$ ) at upper right and the Valira d'Orient $(1561 \mathrm{~m})$ at lower left. The steep forested slope at center contains the studied sequence of approximately 10 antislope scarps (which can be seen as small nicks in the skyline profile) and our three trench sites.

\section{Geological Setting}

Geologically the Encampadana massif is located in the Central-Eastern part of the Pyrenean Axial Zone. The geology of the Central Pyrenees was described by Hartevelt (1970), Zwart (1979), and Barnolas and Chiron (1996). The massif belongs to the synclinorium of TortCasamanya which is arranged in a E-W direction. The bedrock of the study area is composed of rocks of Paleozoic age (Silurian to Mid Devonian). An updated summary of the composition and stratigraphy of the geological formations outcropping in the massif is provided by Clariana (2004) and references therein.

The stratigraphical succession in the Encamapadana massif includes the following materials:

(i) Cambro-Ordocian rocks, which outcrop in the Northern part of the slope (Fig. 3). They consist of dark coloured phyllites, quartz-phyllites and light coloured quartzite layers with thicknesses ranging from a few millimetres to a few metres. They are assigned to the Seo formation (Hartevelt, 1970)

(ii) Silurian rocks, (Hartevelt, 1970) which are mainly composed of black carbonaceous shales and of an alternation of black limestones and shales in the upper part. The Silurian rocks are intensely foliated and folded. The unit has variable thickness because it is often the decollement level of the Pyrenean thrusts and this causes shearing and squeezing of the beds. Locally this unit forms diapiric structures of incompetent behaviour (Zwart, 1979). Silurian rocks appear strongly weathered in outcrop. They are characterized by rusty brown yellow and white colors due to oxidation of pyrite and subsequent sulphur precipitation. 


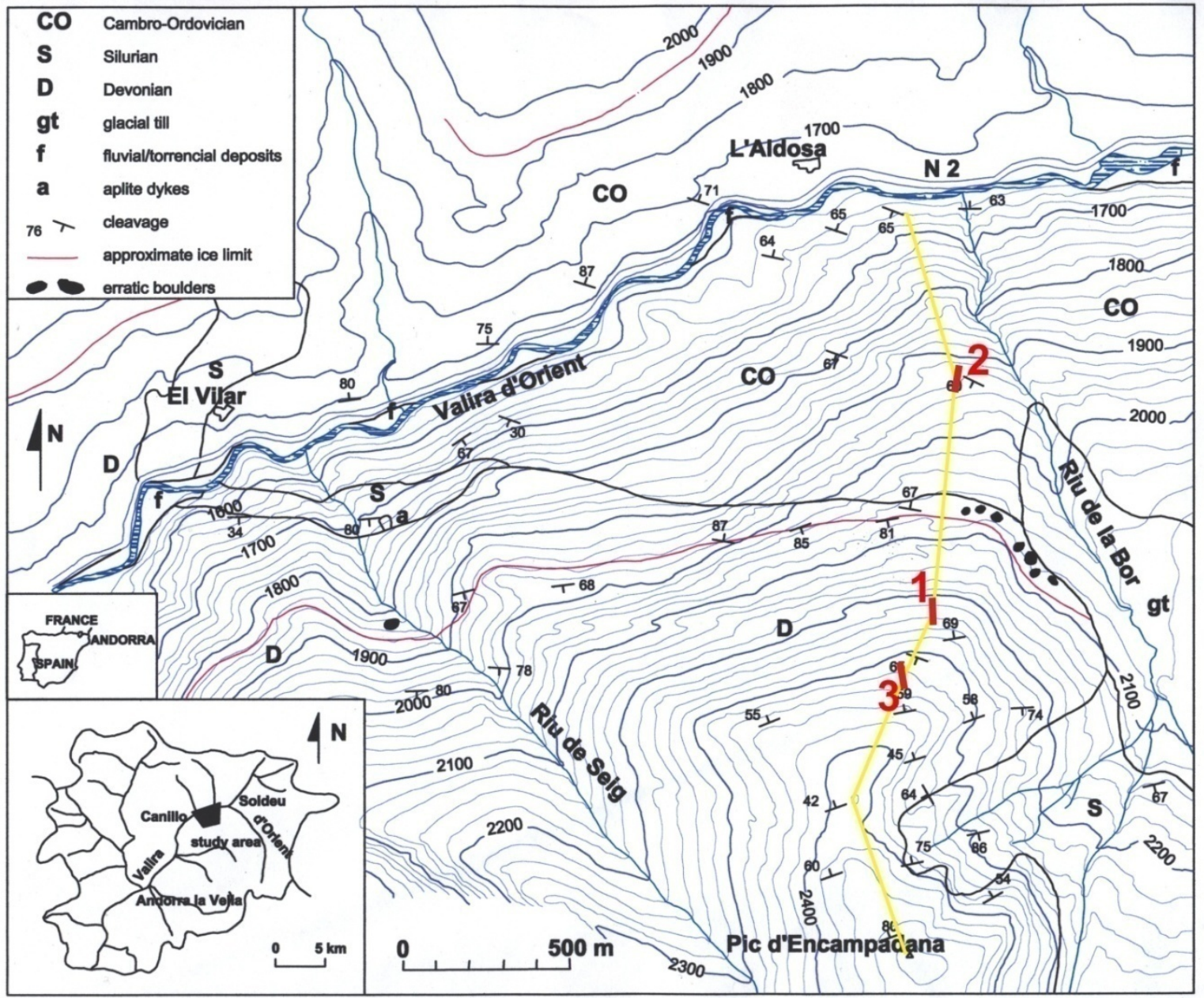

Fig. 3. Geologic map of the northern slope; contour interval $20 \mathrm{~m}$. Yellow line shows line of topographic profile in Fig. 4. Trenches 1, 2, and 3 in red.

(iii) The Devonian series range from lutites and calcareous lutites interbedded with thin limestones layers (Rueda formation) to massive (up to $60 \mathrm{~m}$ thick) limestones and marly limestones (Castanesa Formation), and to green to beige marly limestones (Manyanet formation). All these materials have undergone long and complex deformation processes, due to the superposition of the Alpine orogeny over the previous Variscan phase of deformation.

From a structural point of view, pre-Carboniferous rock formations strike E-W or ENE-WSW. They define antiformal and synformal domes of kilometric extent, bounded by faults and thrusts with the same orientation. The Encampadana massif is mostly composed of Devonian rocks overlaying the Silurian shales. The latter outcrop at the Collet de les Solanelles and farther East.

\section{Glaciation of Andorra and the Valira d'Orient}

Within the past decade the chronology of Pleistocene glaciation in the Pyrenees has been significantly revised based on new suites of numerical ages from: (1) glacial landforms obtained with in situ-generated cosmogenic radionuclide (CRN);(2) glacio-fluvial outwash sediments obtained with optically stimulated luminescence (OSL); and (3) from the cross-correlation of 
these dates with the radiocarbon ages of the ice-marginal deposits (Calvet et al. 2011). The largest remaining data gap is uncertainty on the extent of pre-Würmian glaciers. During the Würmian maximum ice extent W(MIE), glaciers often buried, eroded or reworked the terminal deposits of earlier glaciations, thus hiding their evidence in today's landscape. An updated review of history of the glaciations in the Pyrenees can be found at Calvet et al. (2011), Delmas, (2015), and in the references therein.

During the Last Glacial cycle in the Pyrenees, glaciers occupied much of the territory. On the southern side of the range glaciers were confined within the Pyrenean valleys and reached lengths of 20-30 kilometers, with the fronts located between 800-1000 meters elevation (Calvet, 2004). According to Delmas (2015), the WMIE in the Pyrenees occurred during MIS 4 (74-60 ka). This and other recent studies (Calvet et al. 2011; García-Ruiz et al. 2013; Turu et al. 2016) conclude that several episodes of high magnitude glacier advance and retreat existed after MIS 4. However, the number and extent of such fluctuations is still subjected to debate. Furthermore, recent dating in several Pyrenean valleys has shown a contrasting behavior of glaciers. Depending on the valley, glaciers reached their respective WMIE at different times, often long before the global Last Glacial Maximum (LGM) (Calvet et al., 2011; Delmas et al., 2011; Delmas, 2015).

Subsequent to the WMIE, Pyrenean glaciers retreated significantly in some valleys (Delmas et al 2011). A major readvance took place around 23-19 ky BP, synchronous with the LGM although it was less extensive than the WMIE (García-Ruiz et al. 2003, 2010; Delmas, 2015). Soon after the LGM the Pyrenean ice margin went into a major and rapid recession. Even before the beginning of the Late-glacial, the main trunk glaciers had already retreated to the upper part of the valleys. After the Oldest Dryas (13.35-13.48ka) the glacier fronts were confined to the cirques (Turu, 2011). During the Younger Dryas (11.56-12.7 ka) glaciers were only capable of reaching the valley bottom and after 10 ka they were confined to the highest cirques (Copons and Bordonau, 1994).

In the Principality of Andorra, the Valira d'Orient glacier had a larger accumulation zone than that of the Valira del Nord and due to its orientation it was relatively sheltered from ablation (Turu et al. 2015). These factors allowed the Valira d'Orient glacier to intermittently dam the proglacial streams of the receding Valira del Nord glacier at the cuvette of Andorra la Vella (figure 1). This situation generated an ice-dammed lake in La Massana, the sediments of which have provided the chronostratigraphic clues for reconstructing the Würmian glacial evolution in Andorra (Turu et al. 2016). The retreat after the WMIE disconnected the glacier of the North Valira from the Great Valira glacier. The former receded upstream of La Massana while the Valira d'Orient receded upstream of Canillo. During the LGM the glacier of the Great Valira reached again Andorra la Vella and was large enough to obstruct again the Valira del Nord Valley. According to Turu et al. (2016), the disconnection of the two glaciers and the formation of the lake took place before $25.64 \pm 0.19$ ka BP $(19,352$ to 30,482 cal BP).

During the WMIE, ice-marginal deposits accumulated on the right bank of the Valirad'Orient river above the village of Canillo, at the Bordes de Montaup, and Bordes de Mereig (Soutadé,1988). The deposits are located approximately 300 meters above the current valley bottom, which indicates the approximate thickness of the glacier as itflowed by the Encampadana massif.

\section{Landslides and DSGSDs in the Central \& Eastern Pyrenees}

Slope failures in the axial Pyrenees are controlled by three mainfeatures (Corominas and Baeza, 1992): (i) The presence of susceptible lithologies. Widespread shallow failures in the 
form of shallow slides and debris flows are associated with unconsolidated deposits of glacial and periglacial origin (e.g. till, glacio-lacustrine deposits, colluvium) although the large rock slope deformations and failures involve weak geological units such as the Silurian shales. A synthesis of the most susceptible ones is included in Corominas (1989). (ii) The erosive action of the Pleistocene glaciers and the incision of the present fluvial network, locally exacerbated by the orogenic uplift, have resulted in a steep relief, which constitutes the main predisposing factor for instability; (iii) The geological structure plays a fundamental role in failures that require the contribution of the planes of weakness such as the deep seated gravitational slope deformations (DSGDD). Main fold axes and thrust fronts follow an East-West orientation. River valleys running parallel to these geological structures display large slope failures as observed in some central Pyrenean valleys (Soeters and Rengers, 1983; Bordonau and Vilaplana, 1986) as well as most of the Andorran valleys (Jarman et al. 2014)

\section{Methods}

Trenching: We excavated three trenches with picks and shovels across sackung troughs near the toe, midslope, and head of the northern slope. Trenches were roughly $60 \mathrm{~cm}$ wide, 4.5-6 m long, and 2-2.5 m deep. The eastern wall of each trench was cleaned and gridded with string, after which we drew a field trench log on graph paper at a scale of 1:15. Those logs were then digitized for this paper. Unconsolidated stratigraphic units were defined based on color, texture, and sedimentary structures. Soil horizons developed on deposits (parent materials) were also identified and labelled according to the $A / B / C$ horizon terminology used in the USA (e.g., Soil Survey Staff, 2014).

Geochronology: Our three trenches were sited in parts of sacking troughs that were closed (or nearly closed) topographic depressions, in hopes that trough sediments would contain organics (amenable to radiocarbon dating) or fine-grained deposits (amenable to luminescence dating). Each trench contained both datable organics and silty sediments. Radiocarbon samples were detrital charcoal or in-situ burn layers, dated by AMS. We used the calibration curve of Reimer et al. (2013) to convert radiocarbon years to calendar years. Fine-grained sediments were dated by the infrared-stimulated luminescence (IRSL) method. The multi-aliquot IRSL method was employed by Glenn Berger at the Desert Research Institute, Reno, Nevada. The polymineralic, non-carbonate, detrital 4-11 $\mu \mathrm{m}$ diameter size fraction was prepared. Laboratory samplepreparation procedures have been outlined elsewhere (e.g., Berger, 1990; Wintle and Huntley, 1980). $U$ and Th concentrations were measured by the thick-source-alpha-particle counting (TSAC) technique (Huntley and Wintle, 1981) on dried powders. K was measured by commercial atomic absorption spectrophotometry. Radioactive secular equilibrium is assumed, and assumption apparently valid for luminescence dating of many sediments but not of all alluvial sediments (Olley et al., 1996). The basic sealed-chamber TSAC test (Huntley and Wintle, 1981) indicates no significant radon loss from the dried sample powders used in the study, except for sample OSL3-3, for which an increase-on-sealing of $14 \pm 4 \%$ in the total TSAC count rate was observed. This increase could indicate that significant radon loss has occurred and is occurring within sediments surrounding this sample.

For IRSL measurements the deep-blue luminescence near the known 410-nm emission from the most K-rich feldspars was chosen for detection (e.g. Aitken, 1998). To convert the sample's fossil light to an absorbed-energy equivalent, calibrated laboratory beta $\left({ }^{90} \mathrm{Sr}-{ }^{90} \mathrm{Y}\right)$ and alpha $\left({ }^{241} \mathrm{Am}\right)$ sources were used. Signal was recorded with an automated, high-capacity Daybreak Nuclear Model 1150 reader using an EMI 9635Q photomultiplier tube. Dose-response curves and other data were processed with software produced by Glenn Berger (e.g., Berger et al, 1987). 


\section{Results}

\subsection{Geology and Geomorphology of the Northern Slope}

The trimline of the Latest Glacial Maximum (LGM) Valira d'Orient glacier crosses the northern slope from about $2100 \mathrm{~m}$ on the upvalley (east) side, to $1850 \mathrm{~m}$ on the downvalley side (thin red line on Fig. 3). The trimline is marked by the sudden appearance of rounded erratic boulders of granitic composition, which contrast to the angular, locally-derived clasts of dark Lower Paleozoic phyllite and slate.

The most abundant geomorphic expressions of DSGSD on the northern slope are contourparallel antislope scarps found from low on the slope to its head at the Solanelles Graben (Fig. 4). Such small scarps have also been referred to in the literature as counter-slope scarps, counterscarps, and uphill-facing scarps. Hurliman et al.(2016) described the slope as follows: "The field data at Encampadana show the typical morphological features of a DSGSD such as a prominent graben at the top of the slope and many large counterscarps. The structural data measured in the area indicated two important discontinuity sets: a subvertical schistosity parallel to the valley axis [our Fig. 4], which favored the general toppling of large slope-parallel blocks, and a subvertical perpendicularly orientated joint system, which divided these rock blocks."

Most scarps on the slope are short (200-400 m), trend east-west, and have a swarm-like pattern in map view. Their east-west strike is about $15^{\circ}$ oblique (clockwise) to the SW-NE-trending topographic contours. Scarp orientation is thus similar to the strike of foliation/cleavage in the metamorphic bedrock. The longest antislope scarp zone is $1500 \mathrm{~m}$ long and lies on the steepest part of the entire slope, about $120 \mathrm{~m}$ above the LGM ice limit (Fig. 5). It consists of three abnormally high antislope scarps each about $500 \mathrm{~m}$ long, which form a left-stepping pattern and descend obliquely across the slope from $\sim 2200 \mathrm{~m}$ elevation at the east end to $2000 \mathrm{~m}$ at the west end. Assuming that the scarps represent displacement on extensional (normal faults), the left-stepping pattern implies a left-oblique sense of displacement (Crider, 2001).

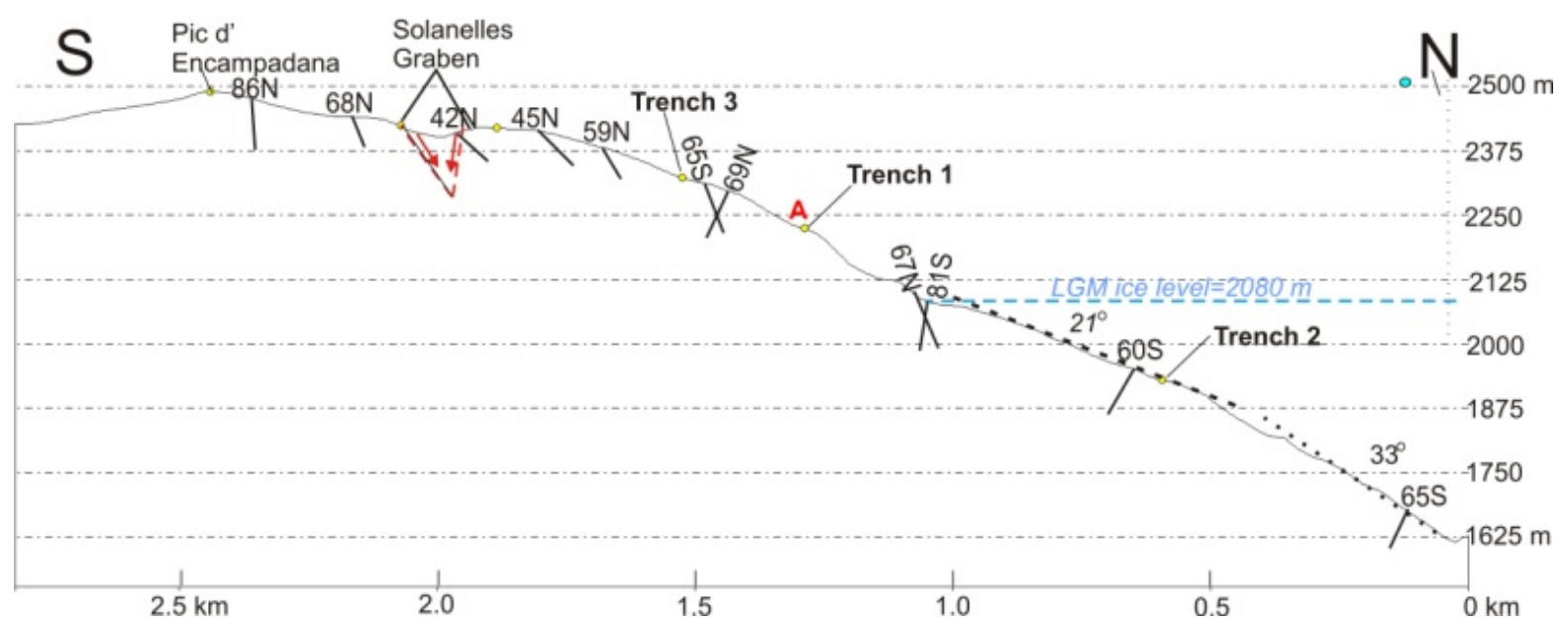

Fig. 4. Topographic profile of the northern slope through our three trench sites (line of section shown in yellow on Figs. 3, 5b). Small black lines with numbers are dip angles of the dominant foliation/cleavage in bedrock. Strike is approximately perpendicular to the section. Red "A" marks the longest $(1.5 \mathrm{~km})$ and highest sackung scarp. 


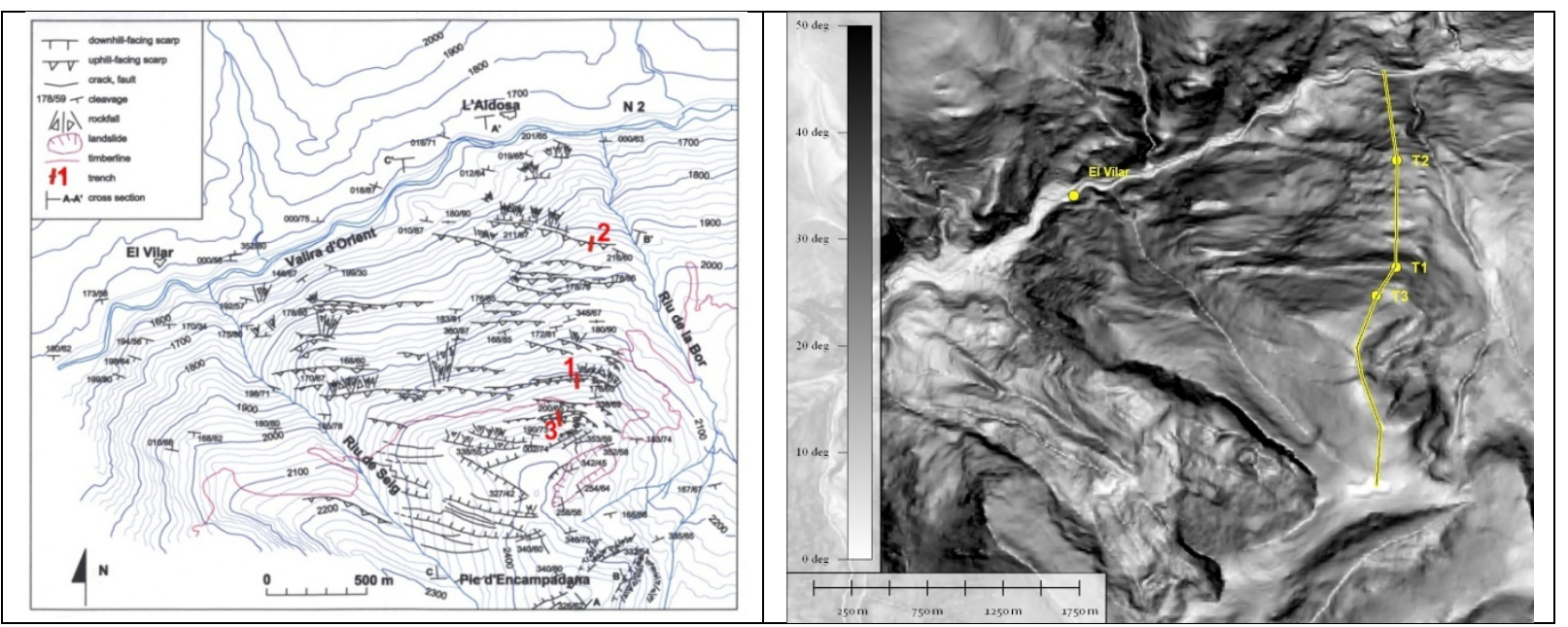

Fig. 5. Maps of slope deformation landforms on the north slope of Pic d'Encampadana. (a) Left, antislope scarps and other landforms related to deep-seated and shallow gravitational deformation. Trench sites are shown in red. Contour interval $20 \mathrm{~m}$. (b) Right, slopeshade image made from a $5 \mathrm{~m}$ lidar DEM (Spanish National Inst. of Geography). Prominent east-west bands on Encampadana's lower slopes are antislope scarps and benches (light) and downhill-facing scarps (dark) created by toppling.

\subsection{Geochronology of Quaternary Deposits and Paleosols in Trenches}

Our age control for deformation events comes from radiocarbon and IRSL dates from sediments deposited in structural depressions (Table 1). This approach to dating deformation events derives from paleoseismic studies of normal faults (e.g. McCalpin, 2009, Chapter 3). Sample locations are shown on the trench logs (Figs. 7, 9, and 12)..

Table 1. Radiocarbon (C-14) and infrared-stimulated luminescence (IRSL) dates from the Andorra trenches (from Berger, 2000).

\begin{tabular}{|c|c|c|c|c|c|}
\hline Trench & Unit & Material & $\begin{array}{l}\text { Dating } \\
\text { Method and } \\
\text { Laboratory }\end{array}$ & $\begin{array}{l}\text { Reported } \\
\text { Age (C14 yr } \\
\text { BP) }\end{array}$ & Calendar Age (cal BP), $2 \sigma^{2}$ \\
\hline 1 & $6 \mathrm{~A}$ & $\begin{array}{l}\text { soil A horizon (organic } \\
\text { sandy loam) }\end{array}$ & AMS/NSF & $1130 \pm 50$ & Cal AD 781 to 1003 (1014-1235 cal BP) \\
\hline 1 & 4 & organic silty loam & AMS/NSF & $3035 \pm 55$ & Cal BC 1122 to 1419 (3139-3436 cal BP) \\
\hline 2 & $10 a$ & $\begin{array}{l}\text { silt matrix of younger } \\
\text { distal colluvium }\end{array}$ & IRSL & & $5.51 \pm 0.37 \mathrm{ka}$ \\
\hline 2 & $5 a$ & $\begin{array}{l}\text { silt matrix of older distal } \\
\text { colluvium }\end{array}$ & IRSL & & $15.3 \pm 1.1 \mathrm{ka}$ \\
\hline 3 & $6 \mathrm{~g}$ & $\begin{array}{l}\text { soil A horizon (organic } \\
\text { silty loam) }\end{array}$ & AMS/Beta & $1490 \pm 40$ & $\begin{array}{l}\text { Cal AD } 442 \text { to } 499 \text {, and } 518 \text { to } 643 \text { (whole } \\
\text { span } 1374 \text { to } 1575 \text { cal BP) }\end{array}$ \\
\hline 3 & $6 a$ & $\begin{array}{l}\text { silty younger sag pond } \\
\text { deposit }\end{array}$ & IRSL & & $8.11 \pm 0.74 \mathrm{ka}$ \\
\hline 3 & $3 a$ & $\begin{array}{l}\text { silty older sag pond } \\
\text { deposit }\end{array}$ & IRSL & & $11.6 \pm 2.1 \mathrm{ka}$ \\
\hline
\end{tabular}

${ }^{1} \mathrm{AMS}=$ radiocarbon, accelerator mass spectrometry; NSF= NSF AMS Facility, Tucson, Arizona; Beta= Beta Analytic, Miami, Florida; OSL dates are infrared-stimulated luminescence dates on the 4-11 micron silt fraction from the Desert Research Institute, Reno, Nevada.

${ }^{2}$ Calendar-year Calibration from CALIB Rev 7.0.4 (2017), using the IntCal13 calibration data set; see http://calib.org (accessed 2017-12-28) and Reimer et al., 2013. Assumes dated samples contain a 50year average of $\mathrm{C}-14$.

IRSL dosimetry data are listed in Table 2. Ages and related luminescence data are listed in Table 3. The Th concentrations seem high, but without additional, detailed data on the spatial distribution of $U$ and $T h$ and without detailed isotopic data, it is necessary to assume that 
conditions of secular equilibrium have applied throughout the samples' burial history. It is also necessary to assume that the estimated past-water-concentration values are accurate and that the measured $\mathrm{U}, \mathrm{Th}$, and $\mathrm{K}$ concentrations from a single sample adjacent to the IRSL sample are representative of the sediment surrounding the sample out to a radius of $\sim 30 \mathrm{~cm}$ (the approximate range of ambient gamma radiation in soil). The measured present water value was used with the samples, with conservative uncertainty assigned.

Table 2. Dosimetry data of Andorra IRSL samples.

\begin{tabular}{|l|l|l|l|l|l|l|l|l|}
\hline Sample & Water & $\begin{array}{l}\mathrm{K}_{2} \mathrm{O} \\
\text { wt.\% } \\
( \pm 0.05)\end{array}$ & $\begin{array}{l}\mathrm{C}_{\mathrm{t}}{ }^{2} \\
\mathrm{ks}^{-1} \times \mathrm{cm}^{-2}\end{array}$ & $\begin{array}{l}\mathrm{C}_{\mathrm{th}}{ }^{2} \\
\mathrm{ks}^{-1} \mathrm{x} \mathrm{cm}^{-2}\end{array}$ & $\begin{array}{l}\text { Th } \\
\mathrm{ppm}\end{array}$ & $\begin{array}{l}\mathrm{U} \\
\mathrm{ppm}\end{array}$ & $\begin{array}{l}\mathrm{b}_{\mathrm{value}}{ }^{3} \\
\mathrm{pGy} \times \mathrm{m}^{2}\end{array}$ & $\begin{array}{l}\text { Dose rate } \\
4 \\
\mathrm{~Gy} / \mathrm{ka}\end{array}$ \\
\hline OSL2-3 & $0.21 \pm 0.05$ & 3.22 & $0.808 \pm 0.014$ & $0.385 \pm 0.048$ & $10.3 \pm 1.3$ & $3.30 \pm 0.39$ & $0.899 \pm 0.076$ & $4.54 \pm 0.23$ \\
\hline OSL2-2 & $0.13 \pm 0.05$ & 2.73 & $0.871 \pm 0.016$ & $0.518 \pm 0.062$ & $13.9 \pm 1.7$ & $2.76 \pm 0.50$ & $0.745 \pm 0.079$ & $4.58 \pm 0.25$ \\
\hline OSL3-1 & $0.34 \pm 0.08$ & 3.43 & $0.907 \pm 0.021$ & $0.649 \pm 0.084$ & $17.4 \pm 2.3$ & $2.01 \pm 0.68$ & $0.691 \pm 0.081$ & $4.26 \pm 0.29$ \\
\hline OSL3-3 & $0.34 \pm 0.08$ & 2.65 & $0.864 \pm 0.017$ & $0.544 \pm 0.064$ & $14.6 \pm 1.7$ & $2.50 \pm 0.52$ & $1.08 \pm 0.27$ & $3.98 \pm 0.34$ \\
\hline
\end{tabular}

${ }^{1}$ Estimated historic average ratio of weight of water/weight of dry sample. Uncertainties here and elsewhere are $\pm 1 \sigma$.

2 Total and thorium count rates from finely powdered samples for thick-source-alpha-particle-counting (TSAC) method [Huntley and Wintle, 1981]. $\mathrm{C}_{\mathrm{u}}=\mathrm{C}_{\mathrm{t}}-\mathrm{C}_{\mathrm{th}}$

${ }^{3}$ Alpha effectiveness factor [Huntley et al., 1988; Berger, 1988].

${ }^{4}$ Calculated with the conversion factors and equations given by Berger [1988] and includes a cosmic ray component of $0.15 \pm 0.03$ estimated from the data of Prescott and Hutton [1988].

292

293

294

295

296

Table 3. IRSL data and ages for Andorra trench samples. ${ }^{1}$

\begin{tabular}{|l|l|l|l|l|}
\hline Sample & Preheat $^{2}$ & $\begin{array}{l}\mathrm{D}_{\mathrm{E}}{ }^{3} \\
(\mathrm{~Gy})\end{array}$ & Time $^{4}$ & Age (ka) \\
\hline OSL2-3 & $140^{\circ} \mathrm{C} / 2 \mathrm{~d}$ & $25.0 \pm 1.1$ & $1-40$ & $5.51 \pm 0.37$ \\
\hline OSL2-2 & $140^{\circ} \mathrm{C} / 2 \mathrm{~d}$ & $69.8 \pm 3.5$ & $1-40$ & $15.3 \pm 1.1$ \\
\hline OSL3-1 & $130^{\circ} \mathrm{C} / 2 \mathrm{~d}$ & $34.6 \pm 2.1$ & $1-15$ & $8.11 \pm 0.74$ \\
\hline OSL3-3 & $130^{\circ} \mathrm{C} / 2 \mathrm{~d}$ & $46.1 \pm 7.2$ & $1-40$ & $11.6 \pm 2.1$ \\
\hline
\end{tabular}

${ }^{1}$ Thepolyminerallic $4-11 \mu \mathrm{m}$ size fraction was used for all IRSL measurements. IRSL was detected at the $420 \pm 20 \mathrm{~nm}$ spectral region (bandpass $390-470 \mathrm{~nm}$ at $1 \%$ cut). All bleaching was for $2 \mathrm{~h}$ with $>780 \mathrm{~nm}$ solar spectrum passed.

2 The chosen pre-readout heating.

${ }^{3}$ Weighted mean equivalent dose plus average error over time interval in next column. A weighted-saturatingexponential regression and error model (Berger et al., 1987) was employed for all samples.

${ }^{4}$ The readout (LED-on) time interval for which $D_{E}$ is calculated.

\subsection{Trench 1}

Trench 1 was located at 2230 m elevation at the eastern end of the longest antislope scarp on the northern slope (Fig. 5). Trench 1 was $4.5 \mathrm{~m}$ long and as much as $2.1 \mathrm{~m}$ deep. The trench axis was oriented $\mathrm{N} 07^{\circ} \mathrm{W}$, perpendicular to the sackung trough.

Local Geomorphology: Trench 1 was located across an asymmetric, contour-parallel trough that occupied the southern half of a $15 \mathrm{~m}$-wide bench. The deepest part of the trough lay up against a very steep slope to the south (Fig. 6, right). We trenched across the topographic low point that supported growth of lush green grass, suggesting fine-grained deposits and occasional ponding. 


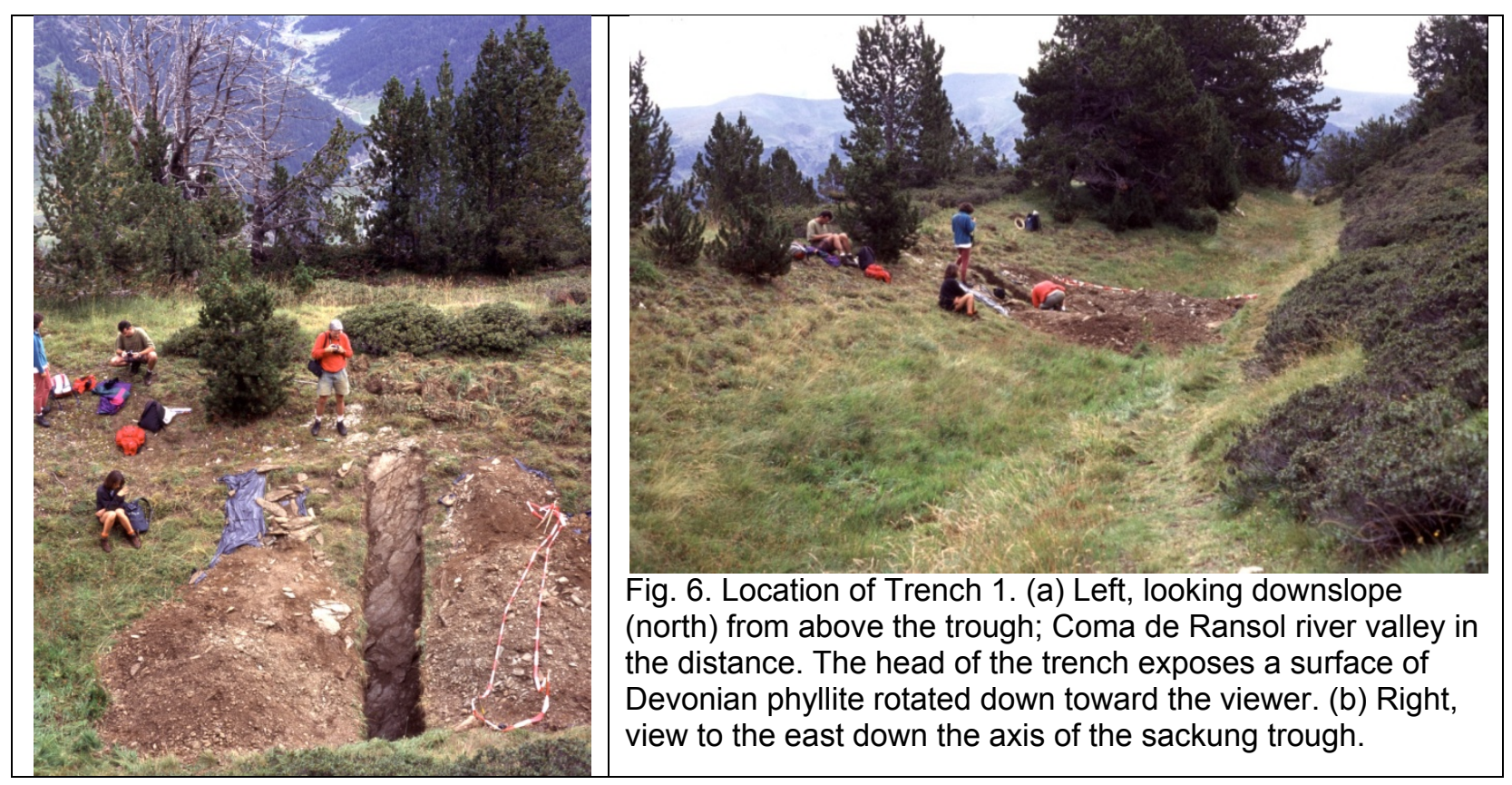

Stratigraphy and Soils: On the east trench wall we define 6 major units, which were further subdivided into 15 subunits (Fig. 7). Unit 1a is the intact phyllite bedrock of the downthrown block (Devonian), and units $1 \mathrm{~b}$ and $1 \mathrm{c}$ are fractured and translocated counterparts of unit $1 \mathrm{a}$. The oldest unconsolidated deposit (unit 2) directly overlies weathered phyllite and is composed of thin, tabular, clays (unit $2 \mathrm{~b}$ ) or clayey loams (unit $2 a$ ) that contain very weathered phyllite clasts. The strong weathering and odd (reduced) colors (green-yellow to golden yellow) suggest that unit 2 was deposited in stagnant water in a closed depression. In the deepest part of the trench (between faults F2 and F3a) unit 2 is overlain by a dark brown silty loam (unit 4). Unit 4 is interpreted as the A horizon of a buried paleosol developed on underlying unit 2. However, outside of faults F2 and F3a, there are intermediate deposits (unit 3) between units 2 and 4 . North of fault F2 the intermediate unit is $3 a$, a gravelly sand with yellow-brown matrix. The unit coarsens toward the north and thus resembles scarp-derived colluvium; it is overlain by the unit 4 paleosol. South of fault F3a units 2 and 4 are separated by a $1.6 \mathrm{~m}$-thick block of strata (unit 3 ) that has been tilted $30^{\circ}-40^{\circ}$ to the south and faulted (faults F3b through F3d). Based purely on color and texture, unit $3 \mathrm{c}$ may correlate with unit $3 a$ in the northern part of the trench. However, that leaves the upper $1.2 \mathrm{~m}$ of stratigraphy in the tilted block (units $3 \mathrm{~d}, 3 \mathrm{e}, 3 \mathrm{f}$ ) with no counterparts in the rest of the trench. Unit 4 drapes the truncated edges of block stratigraphy in angular unconformity. 


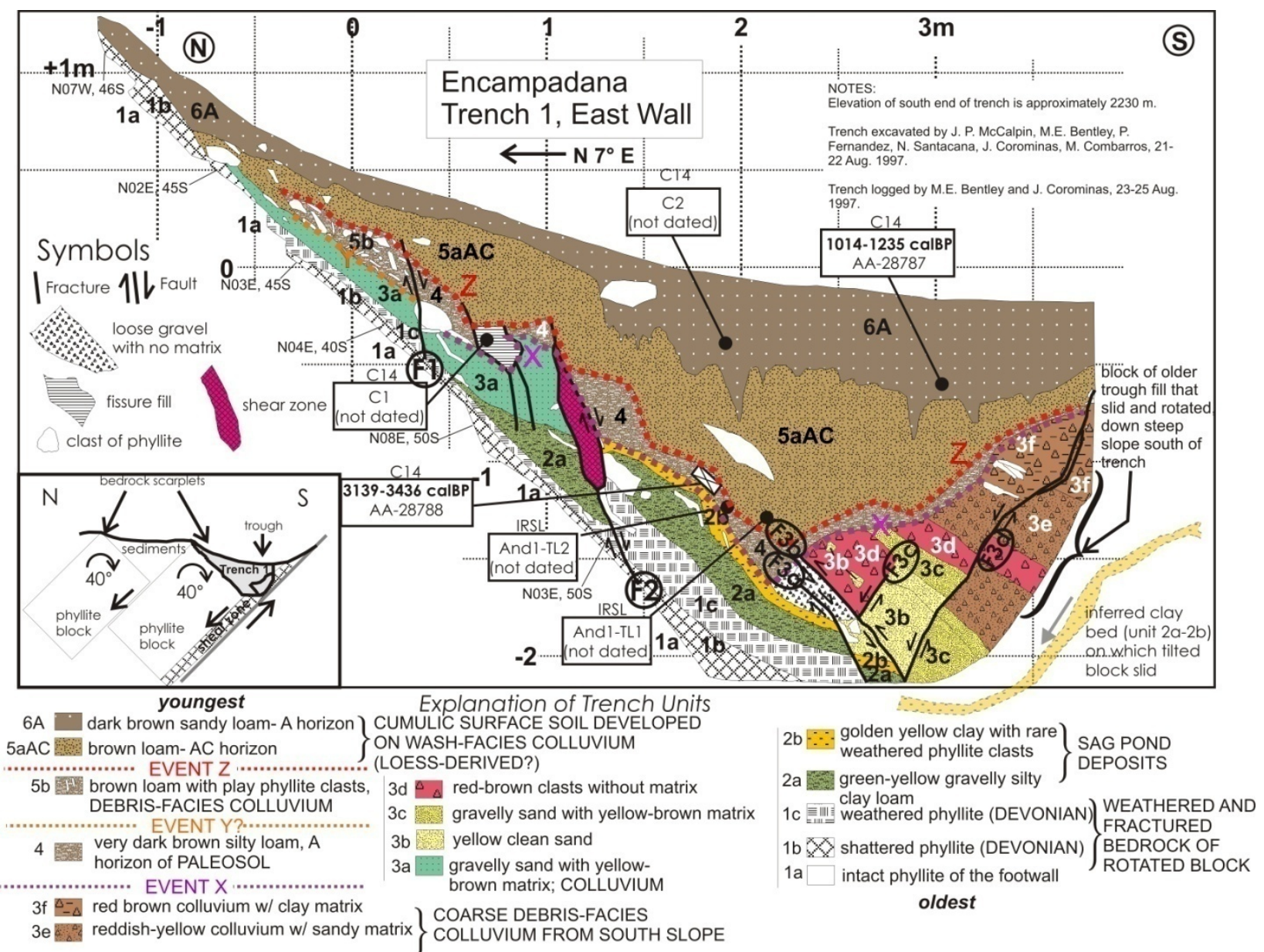

Fig. 7. Log of East Wall of Trench 1. Inset at lower left shows structures and kinematics.

Subsequent to its formation, the unit 4 paleosol has been folded into a $V$-shape. Atop the $V$ are units $5 a$ and 6 , which are poorly stratified brown loam to dark brown sandy loam, respectively. Unit 5a yielded an age of 3139-3436 cal BP. We interpret units $5 a$ and 6 as wash-facies colluvium (slopewash) that has filled in the sackung trough over long periods of time subsequent to the latest deformation event. Soil-forming processes have kept pace with trough aggradation, creating a 1.3 m-thick cumulic soil profile composed of an A horizon (unit 6A) and underlying AC horizon (unit $5 \mathrm{aAC}$ ). North of fault F1 we identified a stone line at the base of unit $5 \mathrm{a}$, which we interpret as debris-facies colluvium (unit $5 b$ ).

Structure: The northern end of the trench is composed of a smooth plane of fractured phyllite bedrock (visible in Fig. 6) which dips $40^{\circ}-50^{\circ} \mathrm{S}$. Faults F1 and F2 are normal faults that splay upward off this bedrock surface at steeper angles. F1 dips $80^{\circ} \mathrm{S}$ and displaces unit $3 a$ about 10 $\mathrm{cm}$ down-to-the-south, whereas F2 dips $70^{\circ} \mathrm{S}$, has a shear zone about $15 \mathrm{~cm}$ wide, and displaces unit $450 \mathrm{~cm}$ down-to-the-south. However, both faults have inconsistent displacement sense and/or amounts as they are traced up and down dip. For example, on F1 unit 4 exists on the south side of the fault but not on the north side. On F2 unit 4 is displaced $50 \mathrm{~cm}$ in a normal sense, but underlying unit $2 a$ is displaced a smaller amount in a reverse sense (down-to-thenorth). Similar mismatches of stratal thickness and displacement across faults are observed on faults F3c and F3d. The thickest part of the trough fill lies between faults F2 and F3a and contains thin clayey deposits (units $2 a$ and $2 b$ ). These were interpreted as basal sag pond deposits, so should have been deposited subhorizontally. But at present they are tilted down-to- 
the-south as much as $50^{\circ}-60^{\circ}$. This degree of tilt is even greater than the $30^{\circ}-40^{\circ}$ southward tilt of strata in the rotated block in the south end of the trench.

Several lines of evidence indicate that the bedrock surface exposed on the north end and floor of the trench is the top of a bedrock block that has been rotated clockwise (down-to-the-south). First, the originally-horizontal sag pond deposits (unit 2) now dip south, which can only have been caused by rotation down-to-the-south (not by outward toppling to the north). Second, with successive rotation the trough deepened, which was accompanied by normal faulting on the south margin of the trough (seen in unit 3 ) and sliding of blocks of exotic stratigraphy into the trough. Third, the presence of two reverse faults (F2, F3b) is an anomaly in a system of rotating domino blocks, normally associated with extension.

Interpreted Sequence of Deformation: Based on stratigraphic superposition, cross-cutting

relationships, and the occurrence of two paleosols, we interpret a sequence of four late Quaternary deformation events at Trench 1, with two more questionable events (Table 1).

Table 4. Inferred sequence of depositional, pedogenic, and deformational events affecting Trench 1.

\begin{tabular}{|l|l|}
\hline Event (oldest at bottom) & Evidence \\
\hline $\begin{array}{l}\text { 11-Deposit units 5b, 5aAC, } \\
\text { 6A }\end{array}$ & $\begin{array}{l}\text { A 1.3 m-thick fining-upward sequence (5b-5a-6) is deposited as wash-facies } \\
\text { colluvium (slopewash), on which is developed a thickcumulic surface soil } \\
\text { (horizons6A, 5aAC). Lower unit 6A yields charcoal age of1014-1235 calBP. }\end{array}$ \\
\hline 10-Deformation EVENT Z & $\begin{array}{l}\text { Youngest event faults unit 5b against unit } 4 \text { on fault F1; faults unit 4 on faults F1 } \\
\text { and F3d. Fault F2 faults unit 4 up to N, but offsets unit 2a down-to-N }\end{array}$ \\
\hline 9-Deposit unit 4 & $\begin{array}{l}\text { Followed by accumulation of organic material in an A horizon Paleosol; ; 3139-3436 } \\
\text { cal BP }\end{array}$ \\
\hline 5-Deformation EVENT Y & $\begin{array}{l}\text { Unit 3 is faulted. Between faults F2 and F3a all of unit 3 is translated away, either } \\
\text { westward by oblique faulting, or it all slides southward to its present location. }\end{array}$ \\
\hline 4-Deposit unit 3 & $\begin{array}{l}\text { Fine-grained units 2a-2b are abruptly buried by coarser colluvial units 3a (derived } \\
\text { from the north) and 3b-3f (derived from the south). }\end{array}$ \\
\hline 3-Deformation EVENT X & Trough deepens due to faulting and clockwise block rotation. \\
\hline 2-Deposit units 2a, 2b & Thin sag pond silts and clays (2a, 2b) accumulate in trough; reduced conditions. \\
\hline 1-Deformation EVENT W & Normal faulting creates the initial topographic trough \\
\hline
\end{tabular}

\subsection{Trench 2}

Trench 2 was located at 1935 m elevation on the lowest-elevation antislope scarp in the Encampadana complex, only $300 \mathrm{~m}$ above the modern valley floor (Fig. 5). Trench 2 was the longest $(6 \mathrm{~m})$ and deepest ( $3 \mathrm{~m}$ of stratigraphic section) of our three hand-dug trenches. The trench axis was oriented $\mathrm{N} 10^{\circ} \mathrm{W}$, perpendicular to the sackung trough.

Local Geomorphology:The trenched antislope scarp/trough is a roughly $500 \mathrm{~m}$ long and follows foliation to the WNW, cutting obliquely across contours that trend WSW. Downslope of this scarp all the mapped scarps face downslope and appear to be part of a late Holocene landslide on the oversteepened lower valley wall.

Stratigraphy and Soils: On the east wall we define 10 major units, which were further subdivided into 23 subunits (Fig. 9). The oldest units (1-5) maintain a tabular geometry throughout the trench, suggesting that they were either: (1) deposited on a uniform slope unaffected by development of a sackung trough and scarp ("Pre-Faulting Units" on Fig. 8), or (2) deposited in a trough much wider and shallower than the present trough. In contrast, units 6-10 are lenticular and are restricted to the northern half of the trench. Each of these five units is located above the 
axis of maximum displacement on faults that were active before its deposition. Thus we interpret units $6-10$ as deposits that accumulated between successive deformation events.

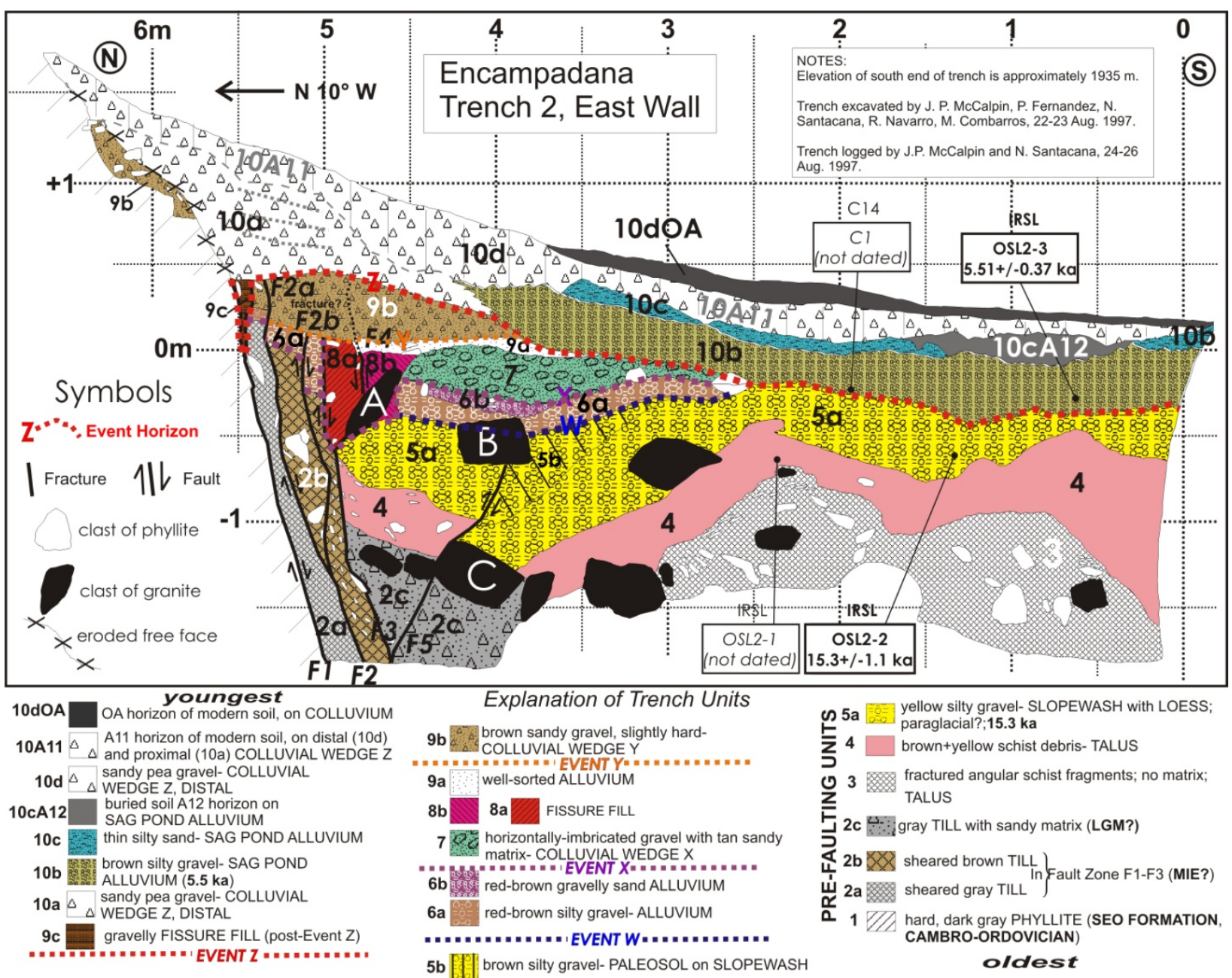

Fig. 8. Log of the east wall of Trench 2.

The oldest deposit exposed in the trench (unit 1) is the hard, dark gray phyllite of the Seo Formation (Cambro-Ordovician) that underlies the lower half of the Encampadana slope. This bedrock unit is only exposed on the footwall of the main south-dipping normal fault beneath the sackung scarp. The oldest in-situ unconsolidated deposit (unit 2c) is a gray, unoxidized till exposed in the deepest part of the trench. The till contains exotic subrounded clasts of granite derived from far upvalley of the Encampadana slope, indicating it was deposited here by the Valira d'Orient glacier. Material derived from this till has been drug up along the main fault zone (units $2 a, 2 b$ ). In the southern half of the trench the oldest deposit (unit 3 ) is composed of angular schist and phyllite fragments with no matrix. This deposit contains no granite and appears to be a locally-derived talus deposit, age equivalent to (or slightly younger than) the gray till. Overlying units $2 \mathrm{c}$ and 3 is a brown, oxidized talus deposit (unit 4) similar in lithology to unit 3 . This talus fines upward into a poorly-sorted yellow silty gravel (unit 5a), the upper part of which has been turned brown by soil formation (unit $5 b$, and paleosol). The base of unit $5 a$ yielded an IRSL age of $15.3 \pm 1.1 \mathrm{ka}$, suggesting it was deposited shortly after the retreat of the LGM glacier. The silt content may be loess deflated from the retreating outwash plain. 
Units 6 through 10 comprise 15 subunits comprised of one of these facies: (1) thin, tabular, wellsorted alluvium, (2) coarser lenses or wedges of poorly-sorted colluvium, and (3) downwardtapering wedges of poorly sorted fissure fill. These facies are all located above deformation structures in the trench, and are interpreted as alluvial and colluvial deposits, respectively, that accumulated episodically in the sackung trough. Unit 10 is the largest of these deposits and contains scarp-derived colluvium (10a) and correlative sag-pond alluvium (10b; basal age $5.51 \pm 0.37 \mathrm{ka}$ ), overlain by thin alluvium and a paleosol (units $10 \mathrm{c}$ and $10 \mathrm{cA} 12$, respectively), distal wash-facies colluvium (10d) and its two soil horizons (10A11 and 10dOA). None of these subunits are deformed, indicating that all deformation occurred after $15.3 \mathrm{ka}$ but before $5.5 \mathrm{ka}$.

425

426

427

428

429

430

431

432

433

434

435

436

437

438

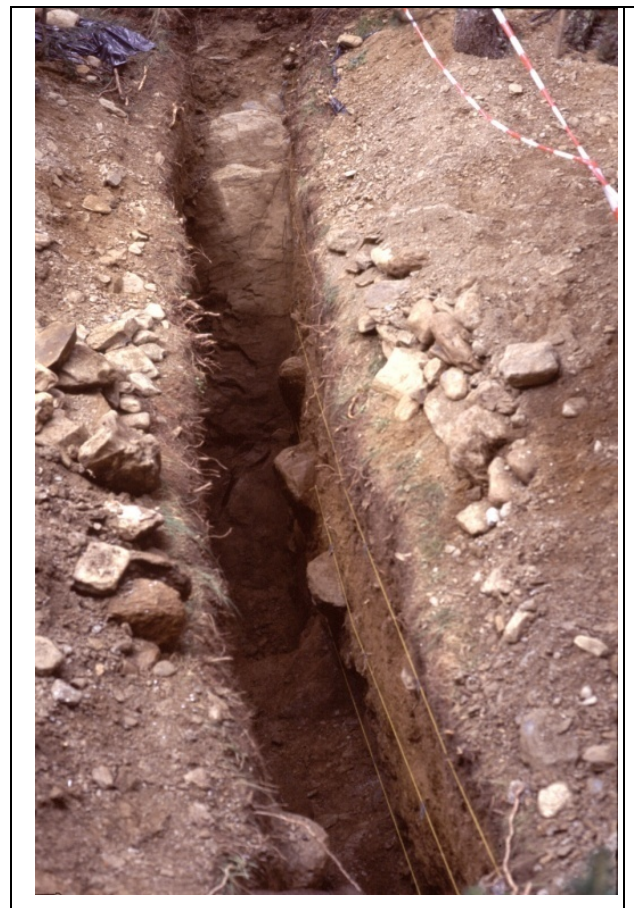

Structure: Trench 2 structures are mainly normal faults, numbered from the footwall to the hanging wall as F1, F2 (F2a, F2b), F3, F4, and F5. Faults F1 through F3 are steeply southdipping normal faults in the main fault zone that underlies (and created) the south-facing sackung scarp (Fig. 9). The fault sliver between F1 and F2 is filled with unoxidized gray sheared till, clearly derived from unit 2c. The sliver between F2 and F3 is filled with an oxidized brown sheared till. F4 is a subvertical fault that splays upward from F3 and bounds the south edge of a fissure fill (unit 8a). F5 is a north-dipping fault that displaces the hanging-wall sequence downto-the-south in an apparent reverse sense. We suspect that some local horizontal compression was generated here by the down-to-the-north rotation of units 3-6 between $2.5 \mathrm{~m}$ and $4 \mathrm{~m}$ on the horizontal grid. As in Trench 1, the down-to-the-north rotation of those units tends to push them northward into their correlatives on the north side of the fault, putting that area into compression.

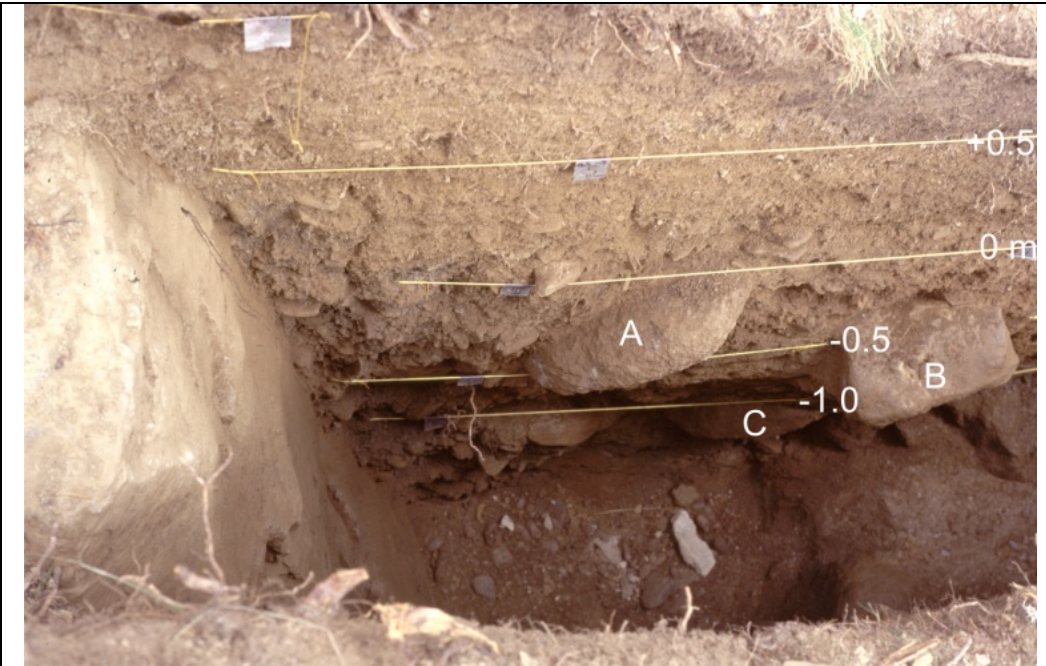

Fig. 9. (a)Left, Trench 2 looking north towards the fault footwall. String lines are $0.5 \mathrm{~m}$ apart. (b) Right: Photo of the east wall of Trench 2 showing phyllite bedrock of the fault footwall (left) and proximal hanging-wall colluvium (center and right); v. Granite boulders labeled $A, B$, and $C$ are also labeled on the trench log (Fig. 8).

Interpreted Sequence of Deformation: The number of deformation events at Trench 2 is evaluated via a retrodeformation sequence (Fig. 10). The sequence starts (Stage A) with the present trench wall geometry and proceeds backwards in time, by a stepwise: (1) removal of any unfaulted deposits, and (2) reversing the fault movement such that the youngest underlying faulted deposits are restored to their continuous (pre-faulting) geometry. Then these deposits 
are removed, and so on to Stage G (geometry of Quaternary deposits before trough formation). This procedure recognizes all upward fault terminations in the stratigraphic sequence, which occur at unconformities separating faulted from unfaulted strata. In paleoseismic investigations such unconformities created by coseismic faulting events are termed "event horizons", a term which we will use in this paper, but not implying in any way that the deformation events are 451 related to earthquakes.

We recognize four event horizons in Trench 2, labeled from $Z$ (youngest) to $W$ (oldest). Event horizons $\mathrm{Z}, \mathrm{Y}$, and $\mathrm{X}$ coincide with scarp-derived colluvial wedges (cwZ, $c w Y$, and $\mathrm{cwX}$ respectively) overlying either older wedges or inter-faulting alluvium. The next older event horizon (W) resulted from downwarping of units 3-5 into a narrow trough, quickly followed by alluvial erosion then deposition (units $6 a, 6 b$ ) in the trough axis. The lack of a colluvial wedge 458 following Event W suggests that no high scarp was formed in this event, but only an extensional 459 fissure. Event W occurred long enough after 15.3 \pm 1.1 ka that a weak paleosol (unit $5 \mathrm{~b}$ ) had 460 formed on the pre-faulting colluvium. Subsequent downwarping of units $6 \mathrm{a}$ and $6 \mathrm{~b}$ beneath unit 4617 (colluvial wedge $X$ ) suggest further sagging occurred in Event $X$. The latest deformation event 462 (Z) occurred immediately before deposition of unfaulted unit $10 \mathrm{~b}$ at $5.51 \pm 0.37 \mathrm{ka}$. Thus, all four 463 deformation events occurred in a time span of $<10 \mathrm{ka}$ ( $<15.3$ to $5.5 \mathrm{ka}$ ). In addition, it is possible 464 that units 2 through 5 were deposited in a pre-existing depression, rather than on a uniform 465 erosional slope. However, our trench exposure was too limited in size to distinguish these two 466 possibilities. 

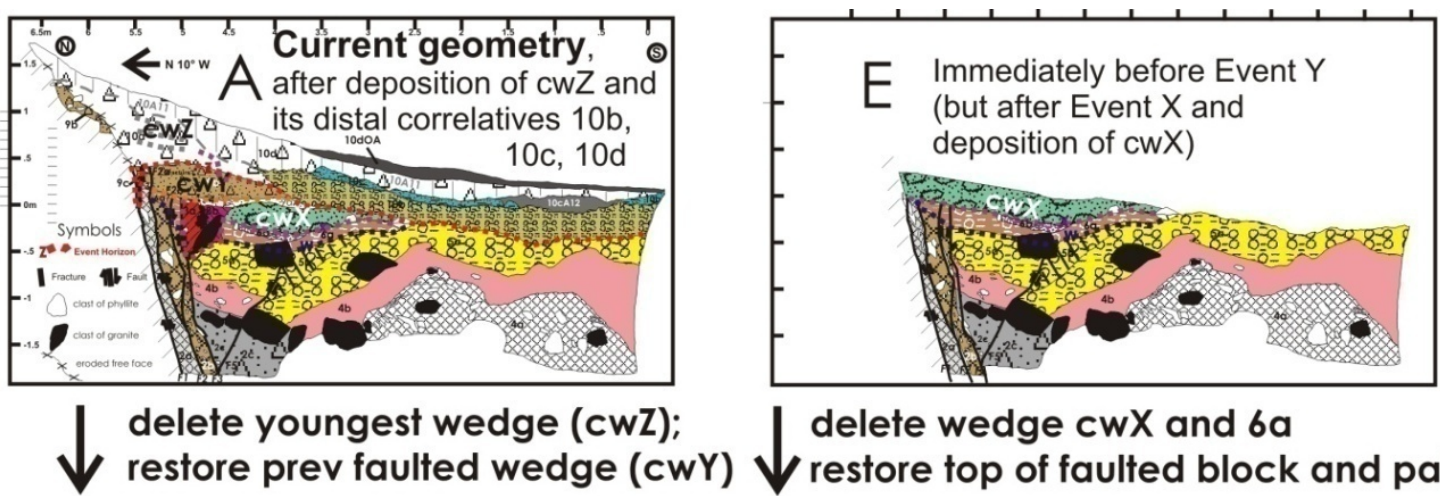

delete wedge $\mathrm{cwX}$ and $6 \mathrm{a}$

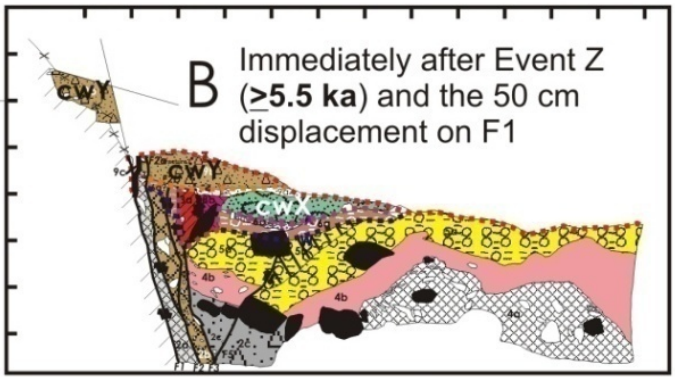

restore top of faulted block and paleosol
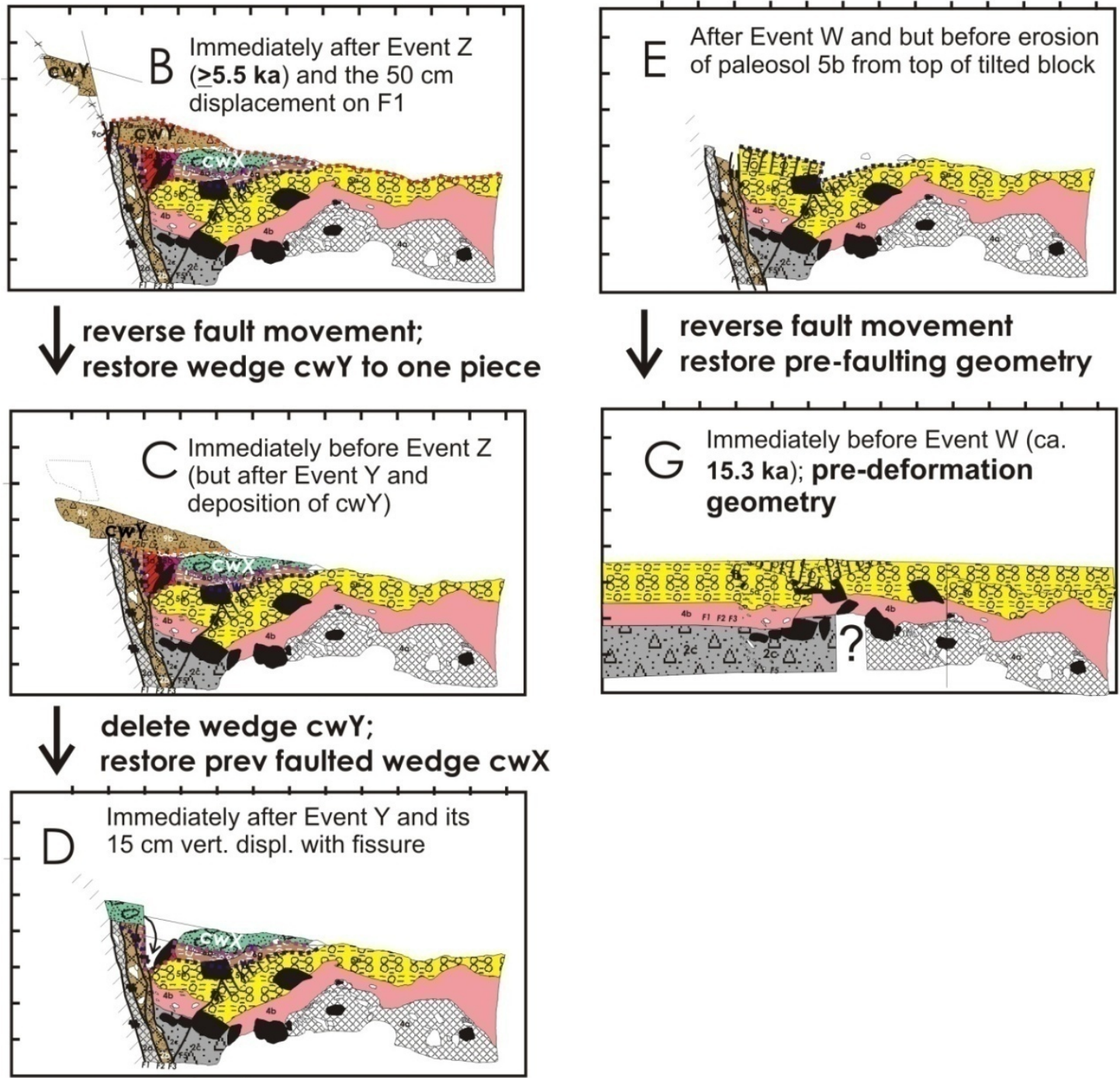
to one piece

Fig. 10. Retrodeformation sequence of the East Wall of Trench 2. Stage A represents the present trench wall geometry, Stage $\mathrm{G}$ the geometry prior to Event W. There may have been additional sackung events prior to Event W, but our trench was not long enough or deep enough to permit reconstruction of the topography of that time. 


\subsection{Trench 3}

Trench 3 was located at 2320 m elevation on the highest-elevation antislope scarp/trough pair in the Encampadana complex (Fig. 5). The trench was $5 \mathrm{~m}$ long and up to $2 \mathrm{~m}$ deep, oriented toward $\mathrm{N} 10^{\circ} \mathrm{E}$ (perpendicular to the trough axis).

\section{Local Geomorphology: Trench 3 crosses the axis of a $\sim 5 \mathrm{~m}$-wide trough which is} topographically closed at the trench site (Fig. 11). We chose the site hoping to expose fine sagpond sediments beneath the center of the closed trough, which might be suitable for C-14 and/or IRSL dating. The trough margins are asymmetrical, with the northern boundary being formed by a 2 m-high near-vertical outcrop of Devonian phyllite, while the southern boundary is a gentler grassy slope underlain by inactive talus.

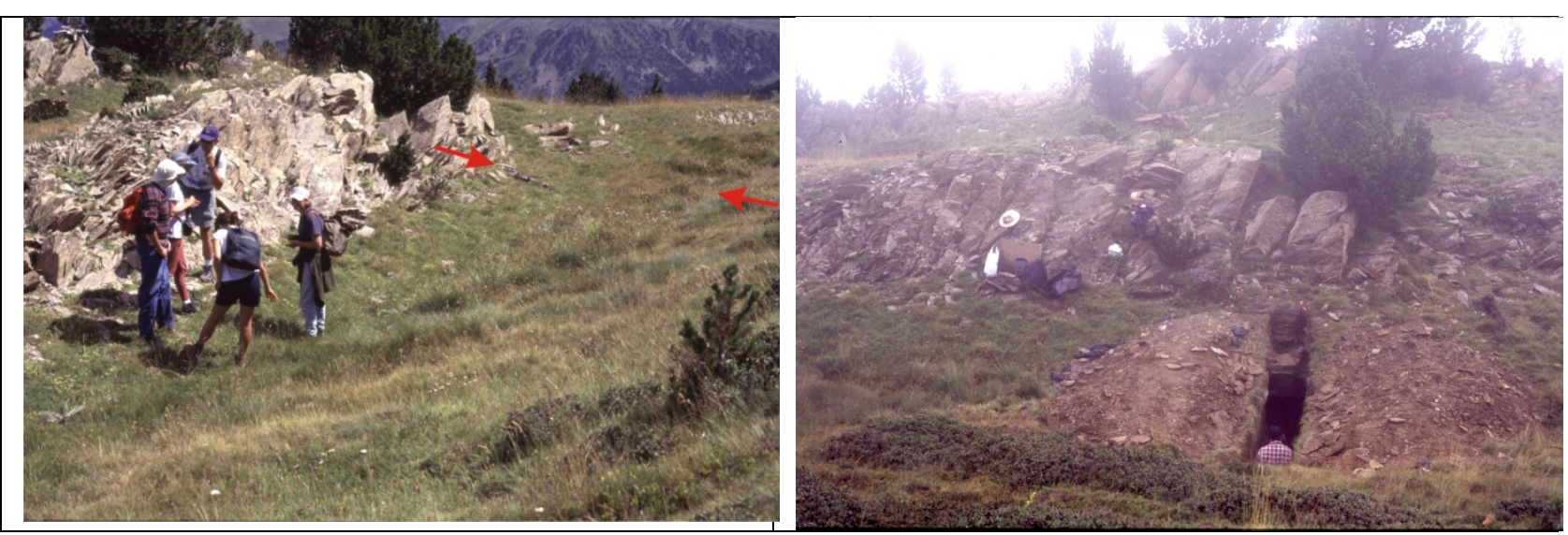

Fig. 11. Site of trench 3. (a) Left, site before trenching, view to NE. Trench was dug between two red arrows. (b) Right, view of trench 3 looking N.

Stratigraphy and Soils: On the east wall we define 7 major units, which were further subdivided into 22 subunits (Fig. 12). The oldest unit (1) is phyllite bedrock (Devonian) of the fault footwall. The oldest unconsolidated deposit exposed is unit 2, mainly a talus deposit composed of angular fragments of phyllite, either without any matrix (unit $2 a$ ) or with a finer sandy matrix ( $2 b$, 2c). The geometry of these deposits does not conform to any of the present structures of topography of the sackung scarp or trough, so we interpret it as pre-trough talus. The shear zone that truncates units $2 \mathrm{a}$ and $2 \mathrm{~b}$ is labeled unit 2 . Younger talus of the hanging wall comprises unit 3 . Unit $4 a$ is a fine-grained deposit (silty clay) that fills a paleo-depression against the shear zone and is the oldest unit with sedimentology consistent with deposition in a closed depression. The base of unit 4 a yielded an IRSL age of 11.6 $\pm 2.1 \mathrm{ka}$, a close minimum age estimate for inception of the sackung trough. Unit $4 \mathrm{a}$ is unconformably overlain by a southward-tapering wedge of much coarser silty clay loam with angular clasts (unit 4b), interpreted as scarp-derived colluvium. Unit 5 is a paleosol developed on unit $4 b$, and to the south, on units $2 \mathrm{~d}, 3 \mathrm{a}$, and $3 \mathrm{~b}$. On the latter units it appears to be developed in a separate, silty (loess-rich?) parent material. [Unit 5 strongly resembles the unit 4 paleosol exposed in Trench 1 , which is also a thin dark grown silty loam that blankets multiple units]. The unit 5 paleosol is unconformably overlain by a second fining-upward of fine-grained sag pond deposits (units $6 a$ through 6f) capped by a paleosol. The bottom of unit 6 yielded an IRSL age of $8.11 \pm 0.74 \mathrm{ka}$. In the center of the topographic trough the A horizon of this soil (unit 6f) is the surface soil. But on the northern and southern flanks of the trough unit $6 \mathrm{f}$ is overlain by younger deposits $(6 \mathrm{~g}$ and $6 \mathrm{~h}$ on the north, $7 \mathrm{a}$ and $7 \mathrm{~b}$ on the south). The center of unit $6 \mathrm{~g}$ yielded a radiocarbon age of 13741575 cal BP. 


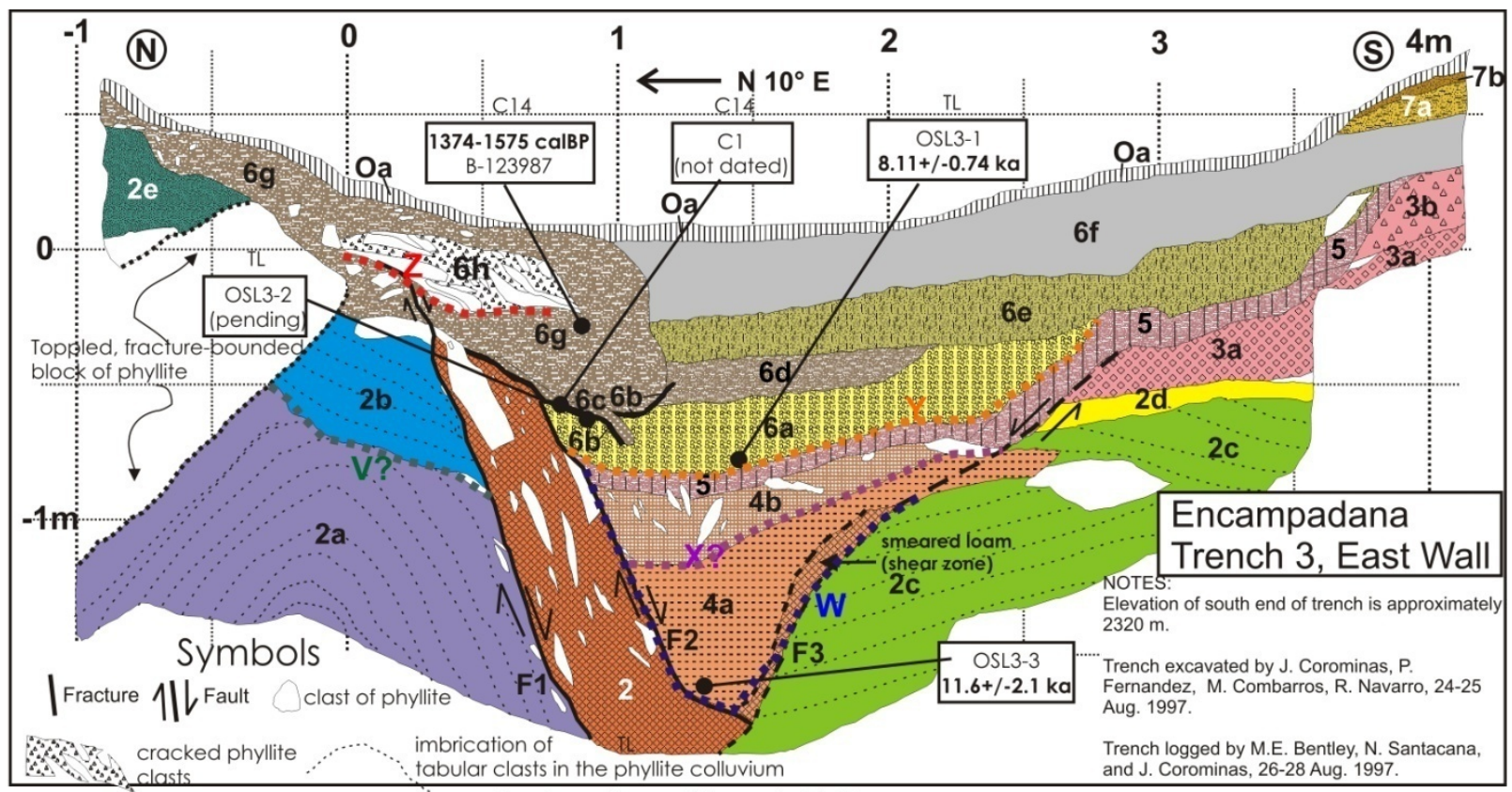

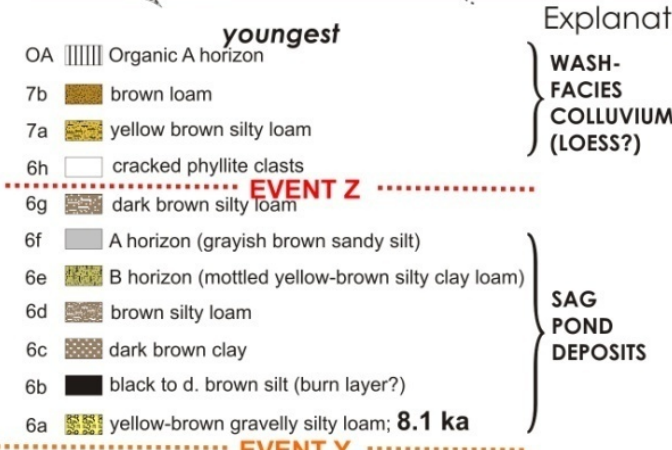

Fig. 12. Log of the east wall of Trench 3. As at Trench 2, the oldest deposits here (unit 2, talus) may have been deposited in an older sackung trough rather than on an undeformed slope. But our limited exposure precludes testing such a hypothesis.

Structure: The trough margins are underlain by inward-dipping normal faults. The northern faults (F1, F2) bracket a $20 \mathrm{~cm}$-thick shear zone (unit 2) containing fault-parallel, tabular clasts of phyllite in a matrix of reddish-brown silty clay loam. Based on color and texture, this matrix was derived mainly units $4 \mathrm{a}$ and $4 \mathrm{~b}$, although there may have a small component from units 5 and 6a. The southern fault $(\mathrm{F} 3)$ has a narrower shear zone $(10 \mathrm{~cm})$ and less overall vertical displacement $(28 \mathrm{~cm})$ than faults F1+F2. The youngest deformation in the trench occurred where fault F1 propagated upward and displaced the lower half of unit $6 \mathrm{~g}$.

In addition to these major extensional structures, there are minor compressional structures. The northern end of the trench exposes an isolated block of phyllite that has toppled southward toward the trough axis. Toppling opened a small void space on the north side of the block, into which unit $2 \mathrm{e}$ was deposited. However, on the south side of the block, stratified talus of unit $2 a$ has been folded into an anticline, indicating local compression. Likewise, the antithetic normal fault F3 now has a rather serpentine shape, as if the originally planar fault was bent by unit 2c pushing northward toward the trough axis. 
Interpreted Sequence of Deformation: Based on stratigraphic superposition, cross-cutting relationships, and the occurrence of two paleosols, we interpret a sequence of three late Quaternary deformation events at Trench 3 , with a questionable $4^{\text {th }}$ event (Table 5).

Table 5. Inferred sequence of depositional, pedogenic, and deformational events affecting Trench 3.

\begin{tabular}{|l|l|}
\hline Event (oldest at bottom) & Evidence \\
\hline 10-Deformation EVENT Z & $\begin{array}{l}\text { On fault F2, the north margin of unit 6a is sheared against unit 2. On fault F1, a small- } \\
\text { displacement fault propagates upward through the lower half of unit 6g. }\end{array}$ \\
\hline 9-Deposit unit 6 & $\begin{array}{l}\text { A } 0.9 \text { m-thick fining-upward sequence (6a-6d) with a 0.25- m surface soil (A horizon, } \\
\text { unit 6f; B horizon, unit 6e). On north side of trough all subunits are intruded by a } \\
\text { solifluction (?) lobe with a basal burn layer. }\end{array}$ \\
\hline 8-Deformation EVENT Y & $\begin{array}{l}\text { Displaces unit 5 paleosol up 0.5 m to south; forms shear zone at unit 4a/2c contact; } \\
\text { deepens trough. }\end{array}$ \\
\hline 7-Deposit units 4b, 5 & $\begin{array}{l}\text { Unit 4b has a sharp contact with underlying unit 4a and is much coarser; but could be } \\
\text { either a colluvial wedge (tapers to south) or debris flow. In contrast, unit 5 is a paleosol } \\
\text { (represents hiatus) on slope-mantling loess. }\end{array}$ \\
\hline $\begin{array}{l}\text { 6-Deformation EVENT } \\
\text { X? }\end{array}$ & $\begin{array}{l}\text { Questionable deformation event. Depends on whether stony unit 4b is a scarp-derived } \\
\text { colluvial wedge, or a debris flow. }\end{array}$ \\
\hline $\begin{array}{l}\text { 5-Deposit sag pond silt in } \\
\text { trough }\end{array}$ & $\begin{array}{l}\text { Sag pond silt (unit 4a) has no correlatives outside of the inner trough (i.e., south of fault } \\
\text { F3). }\end{array}$ \\
\hline 4-Deformation EVENT W & Extensional faulting/fissuring on faults F1-2-3 creates a narrow topographic trough. \\
\hline $\begin{array}{l}\text { 3-Deposit units 2b, 2c, 2d, } \\
\text { 3a, 3b }\end{array}$ & Talus sourced from the south \\
\hline $\begin{array}{l}\text { 2-Deformation EVENT } \\
\text { V? }\end{array}$ & $\begin{array}{l}\text { Unconformity on footwall; unit 2a talus is folded into an anticline, but overlying unit 2b } \\
\text { talus is not folded. Possibly not due to deformation; could be depositional? }\end{array}$ \\
\hline 1-Deposit unit 2a TALUS & Source is upslope to the South \\
\hline
\end{tabular}

\section{Discussion}

Our three trenches sampled only three of the $\sim 50$ antislope scarps on the northern slope, so our interpretation of the larger pattern of slope kinematics may be viewed as preliminary. However, we do see some trends that we believe can be generalized over the entire deforming slope.

\subsection{Reconciling Extensional and Compressional Structures in a Single Trench}

The conventional explanation of DSGSD is that it accommodates valleyward movement mainly by toppling (need References), which is essentially an extensional process. Our trenches show dominantly extensional structures, but each one also contains minor compressional structures (reverse faults and folds). Does this mean that the entire gravitational stress field on the mountain slope is switching from extension to compression and back to extension? Or does it reflect a very local response to changing subsurface geometry as the sackung slope elements rotate and evolve? We believe the latter, for reasons explained below.

Trench 1: This trench shows some small-displacement reverse faults in the lower part of the trough fill, as well as horizontal 'squeezing' of the unit 4 paleosol to attain slopes exceeding the angle of repose. Our first thought was that horizontal compression was caused by slump blocks (unit 3) sliding into the trough from upslope. The toes of such slump blocks would press against the sediments already deposited in the trough, causing local compression. However, such compression should also deform the toe of the slide block, and strata in the supposed slide block (unit 3) are not so deformed. Another possible source of compression would arise if adjacent bedrock blocks rotated a different amount, which would cause compression in the back edge of the sediment wedge. As long as two adjacent 'domino blocks' rotate the same amount, the fault movement along their boundary fault will be purely translational (i.e., a normal fault; Fig. 13A). However, if the downhill block rotates more than the uphill block, the sediment wedge 
(which sits atop the downhill block) will also be rotated (Fig. 13B). That rotation, even across a pivot point located on the fault, will pivot the sediment wedge into the uphill block, such that the back edge of the wedge will be forced into the uphill block, trying to occupy the same space. The result will be compressional deformation of the softer trough sediments, and this will increase as the difference in rotation angle increases.

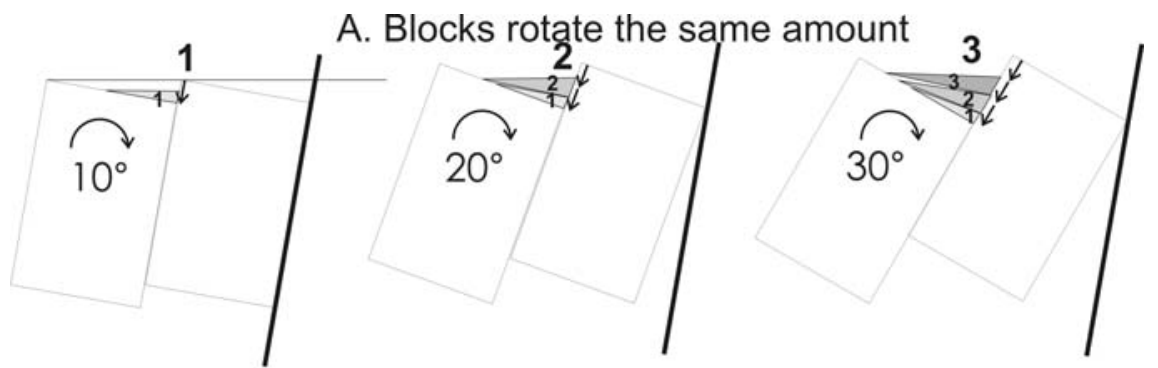

B. Downhill blocks rotate more

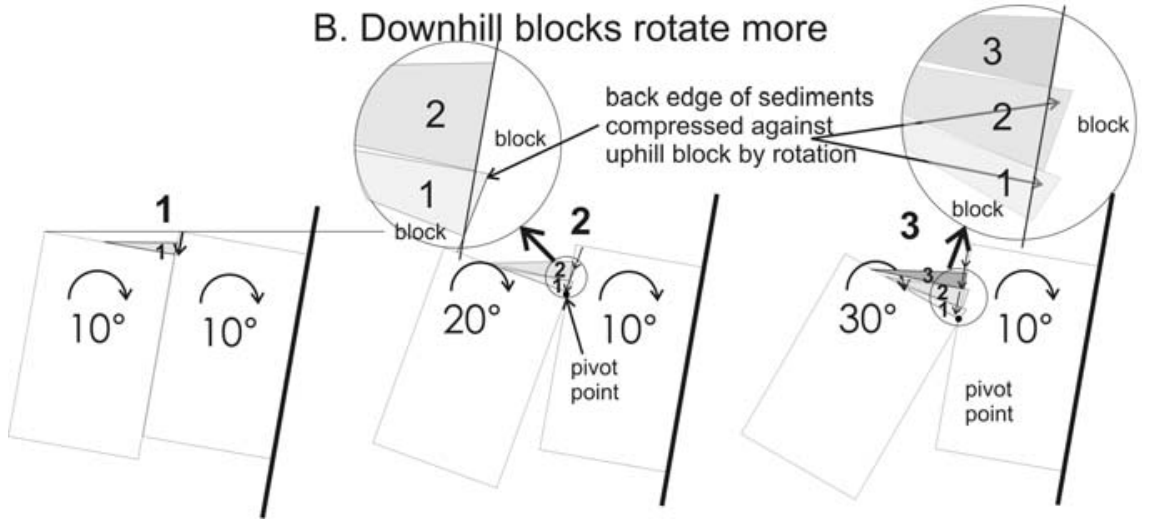

Fig. 13. Schematic diagrams of a pair of gravitationally-rotated bedrock blocks where sediments fill the trough created by rotation. (A), both blocks rotate the same amount through time; sediment wedges 1, 2, and 3 (gray shades) accumulate. (B), the downhill block rotates more than the uphill block, using a pivot point on the fault plane where the two blocks touch (small black circle). As the difference in rotation increases, the back edge of the earlier sediment wedges gets pushed horizontally into the uphill bedrock block, inducing compression in the trough sediments.

Trench 2: Trench 2 contains a master south-dipping normal fault with a smaller north-dipping reverse fault splaying upward into the hanging wall sediments (Fig.8). Secondary reverse faults have been documented in the hanging wall of historic normal fault scarps (e.g., Crone et al., 1987) and observed in many paleoseismic trenches across tectonic normal faults (McCalpin, 2009 , p. 215-219). The causes may range from upward fault refraction (in response to decreasing confining pressures near the surface, to a piece of the hanging wall sediments getting cemented to the fault plane, and thus attached to the footwall in succeeding displacements. Neither explanation seems applicable to the reverse fault in Trench 2. Instead, the reverse fault is contiguous with a section of hanging-wall sediments that were rotated down toward the master normal fault. Units 3 (?), 4 and 5a appear to compose a domino block that has rotated down-to-the-north, toward the reverse fault. As at Trench 1, this rotation would force the north-dipping units $3-5 a$ to try to occupy the same space as their south-dipping correlative farther north, leading to compression. An alternative explanation would invoke localized collapse into a void space to explain the northward dip of units 3-5a. In that scenario units 3-5a between 2.5-4 $\mathrm{m}$ on the grid are sagging downward into a subsurface void, perhaps created by fault refraction of the master normal fault in Event W. But for some reason the northernmost parts of units 3-5a have been cemented to the main shear zone, so they have moved upward as part of the footwall, at the same time that their counterparts farther south have collapsed 
601

602

603

604

605

606

607

608

609

610

611

612

613

614

615

616

617

618

619

620

621

622

623

624

625

626

627

628

629

630

631

632

633

634

downward into the void space. This differential movement has created a fault with the sense of a reverse fault, but with no horizontal compression involved.

Trench 3: During logging of Trench 3 we assumed that the anticlinal folding of unit 2a was entirely caused by slow forward toppling of the phyllite block. However, the upper part of the toppled block lies against unit $2 \mathrm{~b}$, which is not folded. So it seems that, in this trench, a more far-field source of compression may be required. In the southern half of the trench, normal fault F3 contains an anomalous northward bulge, a very odd shape for a tensional fault. Northward slippage along bedding planes in unit $2 \mathrm{c}$ could explain that bulge, but such slippage would require compression coming from outside of the trench, somewhere up the slope to the south. Both deformation structures appear to be plastic deformation of coarse-grained sediments, which suggests slow, creep-style deformation, rather than rapid, episodic (brittle) deformation. As shown in Fig. 14, upslope of trench 3 there is a large downhill facing scarp. A rock wedge is located between this scarp and the footwall of trench 3. So a possible source of far-field compression is that this rock wedge has slid down and compressed the entire area around Trench 3.

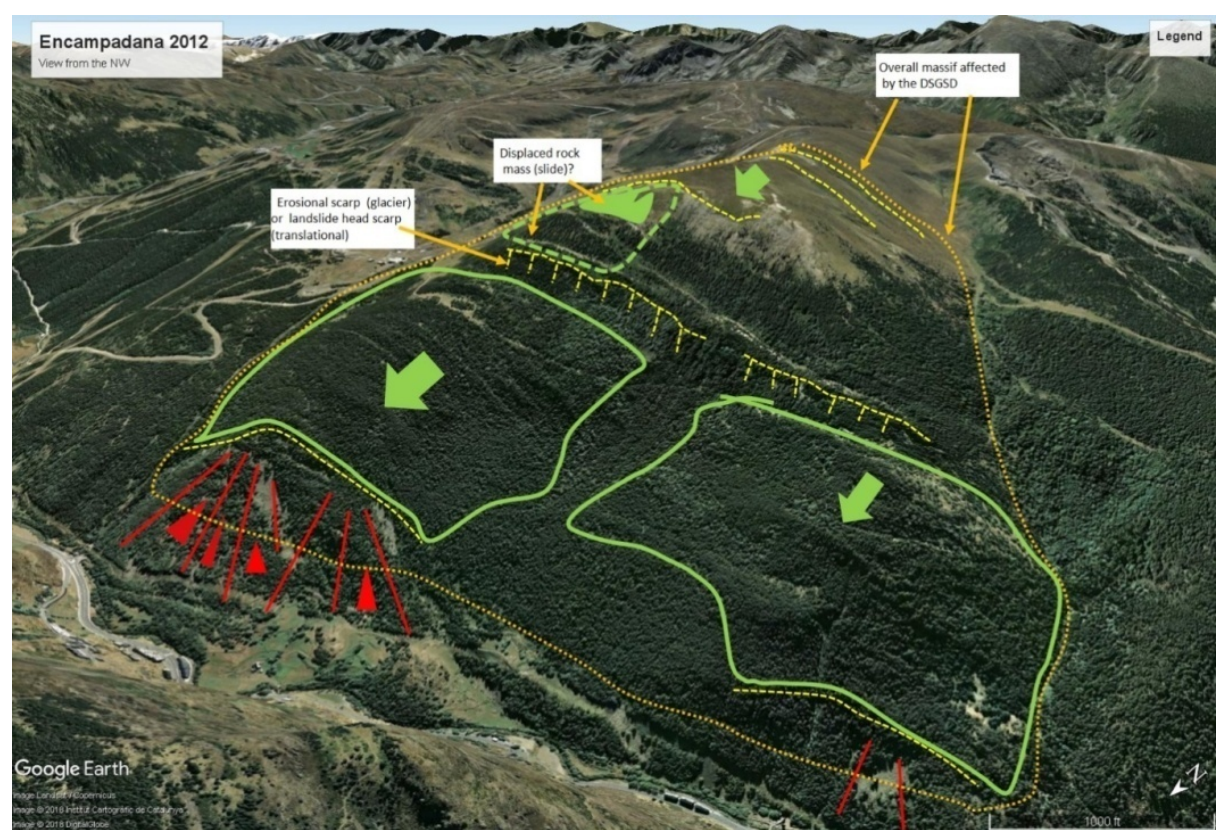

Fig. 14. Overall view of the Encampadana massif. In the foreground (red color) scree deposits (the local place name here is EI Tarter, meaning "scree"). The longest scarp at mid-slope (yellow dashed line) suggests that in addition to toppling some translational movement has occurred (green arrows). Upslope of the long scarp lies a smaller, inferred displaced rock mass. Trench 3 lies in the downslope half of this rock mass.

The timing of compressional deformation is also different among the trenches. In Trench 1 reverse faulting and folding accompanied the youngest displacement (Event $Z$ ), affecting units at least as young as 3.2-3.4 ka. In Trench 2 the reverse fault is much older, moving only in the oldest of the four recognized displacement events (Event W, slightly younger than $15.3 \mathrm{ka}$ ). Compressional deformation in Trench 3 is also old, affecting only units older than $6 a$, which is $8.1 \mathrm{ka}$. The cessation of compressional deformation thus varies widely among the trenches, so much that it cannot represent a mountain-wide change in the stress field, but rather some more localized phenomenon. 


\subsection{Evolution of Deformation over the Whole Slope at Encampadana}

Our trench geochronologies indicate that antislope scarps and troughs first formed low on the slope (Trench 2) by $15.3 \mathrm{ka}$, but deformation there had stopped prior to $5.5 \mathrm{ka}$. At the midslope position (Trench 1) deformation continued until later, with the latest event $(Z)$ just after 31393436 cal BP. Farther up the slope (Trench 3 ) the latest event $(Z)$ was even younger, occurring after 1374-1575 cal BP. In addition, there are morphologic indicators of displaced rock masses and downhill-facing scarps farther upslope of Trench 3. Taking into account the structural style of deformation in each trench and the timing of deformation events, we have constructed a schematic cross-section through the northern slope of Encampadana (Fig. 15). This crosssection makes several assumptions:

(1) the pervasive antislope scarps in the downhill half of the section were created by bedrock blocks, bounded by subvertical foliation planes, that have toppled valleyward;

(2) the top of each toppled block is parallel to today's ground surface;

(3) the resulting amount of toppling is greater toward the toe of the slope. This could be because slope deformation started earlier there (as indicated by trench geochronolgies);

(4) the steep, long scarps in the midslope position reflect an area of localized maximum extension;

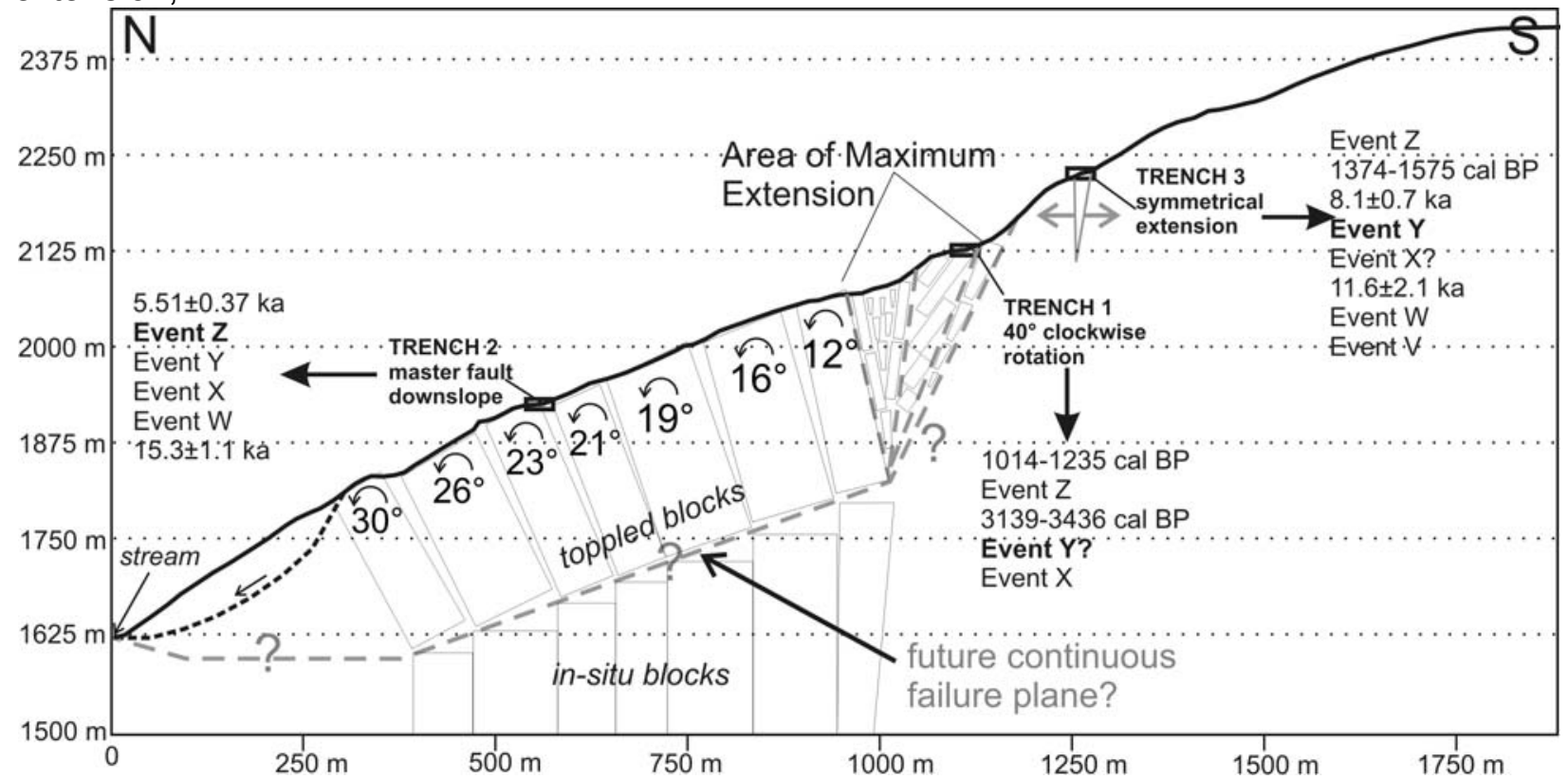

Fig. 15. Interpretive cross-section through the northern slope passing through trenches 1,2 , and 3 . Thick arrows point to the chronology of deformation Events interpreted for each trench, and numerical ages from each trench. The Event with the largest vertical displacement is shown in bold.

(5) this extension has created the severely-back-rotated blocks seen in Trench 1;

(6) in order to achieve such large extensions at the surface, there must be at least an incipient discontinuity between the bottom of the toppled blocks and in-situ bedrock;

(7) the depth of that discontinuity can be approximated at its uphill end by projecting downward the bounding faults in the area of maximum extension;

(8) the downhill end of the potential discontinuity should not be too far below the present (postglacial) valley floor; and

(9) the relatively small, asymmetrical extension seen in Trench 3 suggests it lies outside of the main zone of slope deformation, but perhaps responding to extension from the major gravitational unloading just downslope. 
668

669

670

671

672

673

674

675

676

677

678

679

680

681

682

683

684

685

686

687

688

689

690

691

692

693

694

695

696

697

698

699

700

701

702

703

704

705

706

707

708

709

710

711

712

713

714

715

716

717

718

Other authors have documented similar spatial-temporal trends in DSGSD. In one of the earliest sackung trenching studies McCalpin and Irvine (1995) speculated that antislope scarps would be younger the higher above the glacial trimline, based on the $\sim 2.5-4 \mathrm{kyr}$ lag time between deglaciation and initiation of the highest scarp at the ridge crest. Hippolyte et al., 2009 concluded: "This decrease of the age of the scarps with elevation much probably reflects the propagation of the deformation toward the crest (from elevation $2190 \mathrm{~m}$ to $2419 \mathrm{~m}$ )... This chronology agrees with the proposed mechanism of flexural toppling. The migration of the slope deformation from the valley flank to the crest also supports the model of glacial debuttressing for the origin of the Arcs sackung." El Bedoui et al. $(2009,2011)$ observed a similar trend on the La Clapiere slope in the French Alps. Panek et al. (2017) concluded "In general, we observe a statistically significant correlation showing a progressive decrease of sackung scarp ages with their increasing altitudinal position... Such a relationship might indicate linkage of (delayed) sackung genesis to overall thinning and retreat of glaciers since the LGM... Therefore, slow upslope migration of stress release after glacier withdrawal... could partly explain substantial time lag of a number of sackung scarps." Panek et al. (2017, their Fig. 5) showed a crosssection similar to our Fig. 15, with age control coming from ${ }^{10} \mathrm{Be}$ dating of rock exposed on the sackung scarp face. Their oldest dated antislope scarp was the lowest one, as at Encampadana. However, the next-youngest scarp was at the head of the slope (analogous to the Solanelles graben at Encampadana), and the youngest scarps were in the midslope position. Thus, in hindsight, it appears should have also trenched the margin scarps of the Solanelles graben in order to capture the entire span of slope deformation. We considered this in our initial field reconnaissance, but the graben surface there showed no discrete sediment traps and did not look promising for dating fine-grained deposits. Instead, the entire surface was covered with large-diameter frost-shattered slabs and rubble of phyllite.

\section{Conclusions}

Sackung troughs formed at Encampadana have acted as sediment traps since formation, and are underlain by distinctive postfaulting strata that permit reconstructing the evolution of the antislope scarp and adjacent trough. The oldest strata exposed in our 2-2.5 m-deep trenches are coarse, angular talus deposited as either slope-mantling sediments that predate the modern sackung scarp and trough, or as sediments trapped in a very wide and shallow trough of unknown origin. These deposits have been disrupted by normal and reverse faulting, with the largest fault zone underlying the antislope scarp and dipping south at $40^{\circ}-80^{\circ}$. Each trench contains subsidiary north-dipping normal faults beneath the southern edge of the trough, giving the appearance of a graben. However, in two of three trenches post-faulting deposits have subsequently been tilted or folded down toward the main fault, as if sagging into a void space created by horizontal extension and/or outward toppling of the footwall. The trough fill is generally dominated by poorly-sorted sandy slopewash, but does contain two other important facies: (1) thin clay and silt deposits deposited in standing water, found beneath the center of the trough, and (2) gravelly scarp-derived colluvial wedges, found beneath the edges of the trough. Paleosols have formed on the top of fining-upward sequences of strata, permitting interpretation of several cycles of: (1) episodic downdropping along graben faults and deepening of the topographic trough, (2) filling the trough with marginal colluvial and axial sagpond sediments, followed by (3) a hiatus of soil profile development. The structures and interfaulting sedimentation patterns are very similar to those exposed in trenches across active normal faults (e.g. McCalpin, 2009, Chapter 3).

Despite their shallow depths, each trench preserves evidence of multiple unconformities and 3 to 5 deformation events. Deformation events were recognized by upward termination of faults at various stratigraphic levels, by angular unconformities between trough infill units or finingupward packages, and by coarse, angular colluvial deposits that thin away from the footwall 
(scarp-derived colluvial wedges). The average time span between deformation events in any one trench in the past 12-15 ka is about 3-3.5 ka (e.g., in Trench 2, four events between $15.3 \mathrm{ka}$ and $5.5 \mathrm{ka}$; in Trench 3, successive events at $11.6 \mathrm{ka}$ and $8.1 \mathrm{ka}$ ). Deformation seems to have begun first in the lower part of the northern slope (vicinity of Trench 2) about $15.3 \mathrm{ka}$, and had spread to the upper parts of the slope (Trench 3) by $11.6 \mathrm{ka}$. However, deformation in the lower slope ceased after $5.5 \mathrm{ka}$, but still continued higher on the slope in the mid-late Holocene. The youngest deformation dated (ca. 1.4-1.6 cal ka) occurred in the highest trench on the slope (Trench 3). This pattern of younger deformation with increasing elevation has been documented at several other sites (e.g., Panek and Klimes, 2016) and has been ascribed to an upslopemigrating extensional stress field which originated at the base of the slope from glacial oversteepening and end-glacial debuttressing.

Subsequent to our field campaign, there have been many published studies in which sackung bedrock scarps were dated by cosmogenic radionuclides (CRN). That type of dating study does not require trenching, which is admittedly difficult in many alpine environments. Although such studies do result in an emergence and exposure history of the bedrock scarps, they do not reveal the various sediment facies within the trough nor their deformation structures, and these are necessary to reconstruct the (at least local) kinematics of DSGD deformation.

\section{Acknowledgements}

Molly E. Bentley and Nuria Santacana assisted in mapping the trench walls, and field assistants P. Fernandez, M. Combarros, R. Navarro assisted in excavating and backfilling the trenches. IRSL dating was performed by the late Glenn Berger of the Desert Research Institute. Dating and travel support came from National Science Foundation grant EAR-9506371 to Principal Investigator Peter Birkeland at the University of Colorado, Boulder.

\section{References}

Aitken, M.J., 1998. Introduction to Optical Dating. Oxford Univ. Press, Oxford, UK, 256 p. Barnolas, A., Chiron, J.C. 1996. Introduction. Géophysique. Cycle Hercynien. In A. Barnolas and J.C. Chiron (Eds). Synthèse géologique et géophysique des Pyrénées. Editions BRGMITGE, vol. 2.

Berger, G.W., 1990. Effectiveness of natural zeroing of the thermoluminescence signal in sediments. J. Geophys. Res. 95, 12,375-12,397.

Berger, G.W., 2000. Optical dating of sediments from Lee Vining (California) \& Andorra. Unpub. consulting report submitted to GEO-HAZ Consulting, Inc., Crestone, CO by Luminescence Dating Laboratory, Desert Research Institute, Reno, NV, 04-JAN-2000, 9 p.

Berger, G.W., Lockhart, R.A., Kuo, J., 1987. Regression and error analysis applied to the doseresponse curves in thermoluminescence dating. Nuclear Tracks and Radiation Meas. 13, 177184.

Bordonau, J., Vilaplana, J.M. 1986. Géomorphologie et tectonique récente dans le Val d'Aran (Zoneaxiale des Pyrenees Centrales, Espagne). Revue de Géologie Dynamique et Géographie Physique, 27: 303-310

Calvet, M., 2004. The Quaternary glaciation of the Pyrenees. In: Ehlers, J., Gibbard, P. (Eds.), Quaternary Glaciations-Extent and Chronology, Part I: Europe. Elsevier, Amsterdam, 119-128 
804

805

806

807

808

809

810

811

812

813

814

815

816

817

818

Calvet, M., Delmas, M., Gunnell, Y., Braucher, R., Bourles, D. 2011. Recent advances in research on Quaternary glaciations in the Pyrenees. In: EHLERS, J., GIBBARD, P. \& HUGHES, P. (Eds.), Quaternary glaciations, extent and chronology, A closer look, Part IV. Elsevier, Developments in Quaternary Science, 15, pp. 127-139.,

Clariana, P. 2004. El sinclinori de Tor-Casamanya. Estudie stratigràfic i estructural. Nova cartografia geològica a escala 1:25.000. A Horitzó núm. 6, Revista del Centre de Recerca en Ciències de la Terra. Institut d'Estudis Andorrans. Andorra la Vella.

Copons, R., Bordonau, J. 1994. La Pequeña Edad del Hielo en el macizo de la Maladeta (Alta cuenca del Ésera, Pirineos Centrales). In C. Martí-Bono and J.M. García-Ruiz (eds), El Glaciarismo surpirenaico, nuevas aportaciones. Geoforma Ediciones, Logroño. pp. 111-124

Corominas, J. 1989. Litologías inestables. Monografía $n^{\circ} 3$. Sociedad Española de Geomorfología. Zaragoza. pp: 81-96.

Corominas, J. Baeza, C. 1992. Landslides in the Eastern Pyrenees-Spain. In M. del Prete (Ed): Movimenti franosie metodi di stabilizzazione. Consiglio Nazionale delle Ricerche. Pub. $\mathrm{n}^{\circ} 481$. Italia. pp.: 25-42

Crider, J.G., 2001. Oblique slip and the geometry of normal-fault linkage; mechanics and a case study from the Basin and Range in Oregon. J. Str. Geol. 23, 1997-2009.

Crone, A. J., Machette, M. N., Bonilla, M. G., Lienkaemper, J. J., Pierce, K. L., Scott, W. E., and Bucknam, R. C. ,1987. Surface faulting accompanying the Borah Peak earthquake and segmentation of the Lost River fault, central Idaho. Bull. Seis. Soc. Am. 77, 739-770.

Delmas M., Calvet, M. Gunnell,Y, Braucher, R., Bourles, D. 2011. Palaeogeography and ${ }^{10} \mathrm{Be}$ exposure-age chronology of Middle and Late Pleistocene glacier systems in the northern Pyrenees: implications for reconstructing regional palaeoclimates. Palaeogeography, Palaeoclimatology, Palaeoecology, 305, 109-122.

Delmas, M. 2015. The last máximum extent and subsequent deglaciation of the Pyrenees: an overview or recent research. Cuadernos de Investigación Geográfica, 41: 359-387

El Bedoui, S., Guglielmi, Y., Lebourg, T., Perez, J-L, 2009. Deep-seated failure propagation in a fractured rock slope over 10,000 years: The La Clapiere slope, the south-eastern French Alps. Geomorphology 105, 232-238.

E; Bedoui, S., Bois, T., Jomard, H., Sanchez, G., Lebourg, T., Trics, E., Giglielmi, Y., Bouissou, S., Chemenda, A., Rolland, Y, Corsini, M., Perez, J-L., 2011. Paraglacial gravitational deformations in the SW Alps: A review of field investigations, ${ }^{10} \mathrm{Be}$ cosmogenic dating and physical modeling, In Jaboyedoff, M. (ed.), Slope Tectonics, Geol. Soc. London Spec. Pub. 351, 11-25.

García-Ruiz, J.M., Valero-Garcés, B.L., Martí-Bono, C., González-Sampériz, P. 2003. Asynchroneity of maximum glacier advances in the central Spanish Pyrenees. Journal of Quaternary Science, 18: 61-72 
856

857

858

859

860

861

862

863

864

865

866

867

Garcia-Ruiz, J.M., Marti-Bono, C., Valero-Garces, B., Gonzalez-Samperiz, P., 2005.Large mass movements in relation to deglaciation in the Pyrenees: Proc. $6^{\text {th }}$ Int. Conf. Geomor., Field Trip Guide B-5, Zaragoza, Spain, 17 p.

García-Ruiz, J.M., Moreno, A., González-Sampériz, Valero-Garcés, B.L., Martí-Bono, C. 2010. La cronología del último ciclo glaciar en las montañas del sur de Europa: una revisión. Cuaternario y Geomorfología 24: 35-46

García-Ruiz, J.M., Martí-Bono, C., Peña-Monne, J.L., Sancho, C., Rhodes, E.J., Valero-Garcés, B., González-Sampériz, P, Moreno, A..2013. Glacial and fluvial deposits in the Aragón Valley, central-western Pyrenees: chronology of the Pyrenean late Pleistocene glaciers. Geografiska Annaler: Series A, Physical Geography, 95, 15-32.

Gori, S., Falucci, E., Dramis, F., Galadini, F., Galli, P., Giaccio, B., Messina, P., Pizzi, A., Sposato, A., Cosentino, D., 2014.Deep-seated gravitational slope deformation, large-scale rock failure, and active normal faulting along Mt. Morrone (Sulmona basin, Central Italy).Geomorphological and paleoseismological analyses: Geomorphology 208, 88-101.

Gutierrez, F., Acosta, E., Rios, S., Guerrero, J., Lucha, P., 2005.Geomorphology and geochronology of sackung features (uphill-facing scarps) in the Central Spanish Pyrenees: Geomorphology 69, 298-314.

Gutierrez, F., Ortuno, M., Lucha, P., Guerrero, J., Acosta, E., Coratza, P., Piacentini, D. ,Soldati, M., 2008.Late Quaternary episodic displacement on a sackung scarp in the central Spanish Pyrenees; Seconday paleoseismic evidence?:Geodin. Acta 21, 187-202.

Handwerger, A.L., Rempel, A.W., Skarbek, R.M., Roering, J.J., Hilley, G.E., 2016. Rateweakening friction characterizes both slow sliding and catastrophic failure of landslides. Proc. Nat. Acad. Sci., Earth, Atmos., and Plan. Sci. 113, 10281-10286.

Hartevelt, J.J.A., 1970. Geology of the Upper Segre and Valira valleys, Central Pyrenees, Andorra/Spain: Leidse Geolog. Mededelingen. 45, 167- 236.

Hippolyte, J.-C., Brocard, G., Tardy, M., Nicoud, G., Bourles, D., Braucher, R., Menard, G.,Souffache, B., 2006. The recent fault scarps of the Western Alps (France): Tectonic surface ruptures or gravitational sackung scarps? A combined mapping, geomorphic, levelling, and ${ }^{10} \mathrm{Be}$ dating approach.Tectonophys.418, 255-276.

Hippolyte, J.-C., Bourlès, D., Braucher, R., Carcaillet, J., Léanni, L., Arnold, M., Aumaitre, G., 2009. Cosmogenic ${ }^{10} \mathrm{Be}$ dating of a sackung and its faulted rock glaciers, in the Alps of Savoy (France): Geomorphology108, 312-320.

Huntley, D.J., Wintle, A.G., 1981. The use of alpha scintillation counting for measuring ${ }^{230}$ Th and ${ }^{231} \mathrm{~Pa}$ contents of ocean sediments. Canadian J. Earth Sci. 18, 419-432.

Hurlimann, M., Ledesma, A., Corominas, J., Prat, P.C., 2006. The deep-seated slope deformation at Encampadana, Andorra; Representation of morphologic features by numerical modeling. Engr. Geol. 83, 343-357. 
868

869

870

871

872

873

874

875

876

877

878

879

880

881

882

883

884

885

886

887

888

889

890

891

892

893

894

895

896

897

898

899

900

901

902

903

904

905

906

907

908

909

910

911

912

913

914

915

916

917

Jarman, D., Calvet, M., Corominas, J., Delmas, M. ,Gunnell, Y., 2014. Large-scale rock slope failures in the eastern Pyrenees; identifying a sparse but significant population in paraglacial and parafluvial contexts. Geograf. Ann. 96, 357-391.

McCalpin, J.P., 2003. Criteria for determining the seismic significance of sackungen and other scarplike landforms in mountainous regions, in Hart, E.W. (ed.), Ridge-Top Spreading in California; Contributions toward understanding a significant seismic hazard. Calif. Geol. Surv. CD 2003-05, 2 CD-ROMs.

McCalpin, J.P., 2005. Late Quaternary activity of the Pajarito fault, Rio Grande rift of northern New Mexico, USA.Tectonophys 408, 213-236.

McCalpin J.P., 2013. Trenching and Exposed Faces, in Shroder, J.F., Switzer, A.D., Kennedy, D.M. (Eds.) Treatise on Geomorphology, Vol. 14, Methods in Geomorphology: Academic Press, San Diego, CA, 138-149.

McCalpin, J.P., Bruhn, R.L., Pavlis, T.L., Gutierrez, F., Guerrero, J. ,Lucha, P., 2011, Antislope scarps, gravitational spreading, and tectonic faulting in the western Yakutat microplate, south coastal Alaska. Geosphere 7, 1143-1158.

McCalpin, J.P., Hart, E.W., 2003. Ridge-top spreading features and relationship to earthquakes, San Gabriel Mountains Region, Southern California - Part A: Distribution and description of ridge-top depressions (sackungen), in Hart, E.W. (ed.), Ridge-Top Spreading in California; Contributions toward understanding a significant seismic hazard: Calif. Geol. Surv. CD 2003-05, 2 CD-ROMs.

McCalpin, J.P., Hart, E.W., 2003. Ridge-top spreading features and relationship to earthquakes, San Gabriel Mountains Region, Southern California - Part B: Paleoseismic investigations of ridge-top depressions, in Hart, E.W. (ed.), Ridge-Top Spreading in California; Contributions toward understanding a significant seismic hazard: Calif. Geol. Surv. CD 2003-05, 2 CD-ROMs.

McCalpin, J.P., Irvine, J.R., 1995. Sackungen at Aspen Highlands Ski Area, Pitkin County, Colorado. Environ.Engr.Geosci. I, 277-290.

Mariotto, F.P., Tibaldi, A., 2016. Inversion kinematics at deep-seated gravity slope deformations revealed by trenching techniques. Nat. Haz. Earth Syst. Sci.16, 663-674.

Olley, J.M., Murray, A., Roberts, R., 1996. The effects of disequilibria in the uranium and thorium decay chains on burial dose rates in fluvial sediments. Quat. Sci. Rev.15, 751-760.

Ortuño, M., Guinau, M., Calvet, J., Furdada, G., Bordonau, J., Ruiz, A., Camafort. M., 2017. Potential of airborne LiDAR data analysis to detect subtle landforms of slope failure; Portainé, Central Pyrenees. Geomorphology 295, 364-382.

Panek, T., Klimes, J., 2016. Temporal behavior of deep-seated gravitational slope deformations: A review. Earth. Sci. Rev. 156, 14-38.

Panek, T., Mentlik, P., Ditchburn, B., Zondervan,A., Norton, K., Hradecky, J., 2015. Are sackungen diagnostic features of (de)glaciated mountains? Geomorphology 248, 396-410. 
Panek, T., Mentlik, P., Engel, Z., Braucher, R., Zondervan, A., The Aster Team, 2017. Late Quaternary sackungen in the highest mountains of the Carpathians: Quat. Sci. Rev.159, 47-62.

Reimer, P.J. and 27 others, 2013, IntCal13 and MARINE13 radiocarbon age calibration curves 0-50000 years cal BP. Radiocarbon 55, DOI: 10.2458/azu_js_rc.55.16947.

Soeters, R., Rengers, N. 1983. Dos ejemplos de hundimientos gravitacionales en los alrededores de Caldes de Boí (Pirineos leridanos). In: Geología de España- Libro Jubilar de J.Mª Ríos. IGME. Madrid Vol.3: 193-202

Soil Survey Staff, 2014. Keys to Soil Taxonomy, 12th ed. U.S. Dept. Agriculture, Natural Resources Conservation Service, Washington, DC., USA, 360 p.

Soutadé, G. 1988. Le glissement d'el Forn (Andorra). II Simposio Inestabilidad de Taludes y Laderas Naturales. Andorra la Vella. pp 643-655

Turu, V., 2002. Analisis secuencial del delta de Erts, estratigrafia de un valle glaciar obturado intermitentemente; Relacion con enultimo ciclo glaciar.,Valle de Arinsal, Pirineos Orientales. In: Estudios recientes (2000-2002) en geomorfologia, patrimonio, montana y dinamica territorial. SEG-Departamento de geografi'a UVA edit, Valladolid, 555-574.

Turu, V. 2011. El glacialisme de les valls de la Valira del Nord: evidències d'un englaçament continuat fins a l'Holocè. Resúmenes XIII Reunión Nacional de Cuaternario. Andorra. 6 pp.

Turu, V., Calvet, M., Bordenau, J., Gunnell, Y., Delmas, M., Vilaplana, J.M., Jalut, G., 2016, Did Pyrenean glaciers dance to the beat of global climatic events? Evidence from the Würmian sequence stratigraphy of an ice-dammed paleolake depocentre in Andorra, in Hughes, P.D. and Woodward, J.C. (eds.), Quaternary Glaciation in the Mediterranean Mountains. Geol. Soc. London Spec. Pub. 433, 111-136.

Wintle, A.G., Huntley, D.J., 1980. Thermoluminescence dating of ocean sediments: Canadian J. Earth Sci.17, 348-360.

Zwart, H.J. 1979. The geology of the Central Pyrenees. Leidse Geologische Mededelingen, 50: 1-74 